$3-1-2014$

\title{
Google Search Results: Buried If Not Forgotten
}

Allyson Haynes Stuart

Follow this and additional works at: http://scholarship.law.unc.edu/ncjolt Part of the Law Commons

\section{Recommended Citation}

Allyson H. Stuart, Google Search Results: Buried If Not Forgotten, 15 N.C. J.L. \& TECH. 463 (2014).

Available at: http://scholarship.law.unc.edu/ncjolt/vol15/iss3/4

This Article is brought to you for free and open access by Carolina Law Scholarship Repository. It has been accepted for inclusion in North Carolina Journal of Law \& Technology by an authorized administrator of Carolina Law Scholarship Repository. For more information, please contact law_repository@unc.edu. 


\section{NORTH CAROLINA JOURNAL OF LAW \& TECHNOLOGY \\ VOLUME 15, ISSUE 3: SPRING 2014}

\section{GoOgle SEARCh Results: BuRIED IF NOT ForgotTen}

\section{Allyson Haynes Stuart}

The right to be forgotten or mandatory deletion of online information squarely confronts the First Amendment right to free speech. But the underlying problem provoking advocates of a right to be forgotten is only increasing: harmful information posted online has the real potential to destroy a person's reputation or livelihood. In addition, the way Internet users get their information-search engines, primarily Google-emphasizes harmful information if it is "popular" under Google's algorithm. In response to requests for removal, Google maintains that it cannot control the underlying websites, so removing information from its results is pointless. But, in fact, the search results themselves are of crucial importance. And those results are already being altered. If Internet users' primary access to the vast amount of online information is filtered-and hand-edited-by a search engine, why should that editing not take into consideration the harmful nature of some information? This Article proposes that Google consider "demoting" references to information in its search results that fall within one of several sensitive categories when the party requesting removal has unsuccessfully exhausted her remedies with respect to the website publisher of the information. This amounts not to censorship, but to factoring in the nature of the information itself in determining its relevance in response to search requests.

* Associate Professor of Law, Charleston School of Law. The author would like to thank the participants of the 2013 Privacy Law Scholars Conference, in particular Paul Bernal and Jef Ausloos, for their helpful comments on an earlier draft; and Kelsey Brudvig, Meghan White and Stephanie P. Brown, for their excellent research assistance. 


\section{TABLE OF CONTENTS}

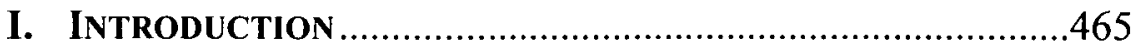

II. GOOGLE AND OUR ONLINE MEMORY …….........................470

A. The Importance of Internet Search ................................470

1. Search Engine Usage .................................................471

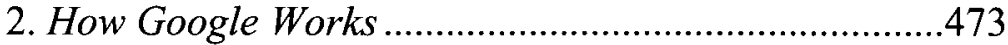

a. PageRank, Popularity, and "Quality".................474

b. "Manual Control and the Human Element" .......476

B. Search Results Have Results ...........................................476

C. The Right to be Forgotten ..............................................479

D. Suppression: A Rising Demand in the United States .......483

III.U.S. LAW's PROTECTION OF SEARCH ENGINES.....................487

A. The First Amendment ..................................................487

B. Section 230 of the Communications Decency Act.............490

C. Privacy Torts ................................................................491

IV. InTERnet SEARCH Results Are Already BeIng Altered

A. Google's Policy on Removal Requests .........................493

B. Google's Action in Response to Removal Requests .........497

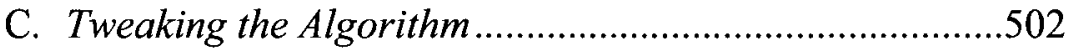

V. The Proposal: Guiding Google's Choices ...................504

A. Categories of Online Suppression .................................505

1. The Information is Confidential and Personal ..........505

2. The Information Relates to a Minor...........................506

3. The Information is Untrue or Defamatory, or No Longer "Relevant"......................................................507

4. The Information is Otherwise Unduly Harmful, such as that Likely to Result in Bullying or Stalking ...............511

B. In Google's Best Interests ................................................512

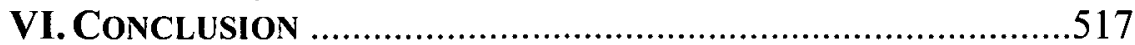




\section{INTRODUCTION}

The "right to be forgotten" is the term that has been applied to an individual's right to control and possibly delete personal information about herself in the hands of others, usually because that information is outdated or no longer relevant such that its continued use violates the privacy rights of the individual. ${ }^{1}$ The European Union ("EU") has taken the lead on an Internet right to be forgotten, proposing in 2012 that individuals should have the ability to require the deletion of their online personal information if the processing or storing of that information is no longer necessary. ${ }^{2}$ This proposal has received a great deal of negative attention in the United States, primarily because of its potential to chill online speech and censor the Internet. The U.S. view rejects the suggestion that online information should be deleted or subject to "erasure," particularly when this erasure involves requesting search engines to remove content posted by third parties. At the same time, the United States has seen a rise in the number of people seeking exactly that: deletion of online information, particularly by search engines. Analogizing search engine deletion requests to Internet censorship ignores an important fact: search engines already filter and edit the Internet. Rather than opposing wholesale the idea of regulating search engine results, we should focus on the way those results are already manipulated. If Internet users' primary access to the vast amount of online information is filtered-and hand-edited-by a search engine, why shouldn't that editing take into consideration the harmful nature of some

\footnotetext{
${ }^{1}$ For background on the right to be forgotten, see generally Franz Werro, The Right to Inform v. The Right to Be Forgotten: A Transatlantic Clash, in Liability IN THE ThiRd Millenium 289 (2009); Steven C. Bennett, The "Right to Be Forgotten": Reconciling EU and US Perspectives, 30 BERKELEY J. INT'L L. 161 (2012).

2 See Viviane Reding, Vice President, Eur. Comm'n, The eU data Protection Reform 2012: MAKing Europe the STANDARd SETTER For Modern Data Protection Rules in the Digital Age 5 (Jan. 22, 2012), available at http://europa.eu/rapid/pressReleasesAction.do?reference=SPEECH/ 12/26\&format=PDF; Jeffrey Rosen, The Right to Be Forgotten, 64 STAN. L. REV. ONLINE 88, 88-89 (2012).
} 
information? Google's ${ }^{3}$ current policy is to refuse requests for removal except in the case of a court order. ${ }^{4}$ This Article proposes that Google consider a middle ground: when requests involve information that falls within one of several sensitive categories, and the party requesting removal has exhausted her remedies with respect to the website publisher of the information, Google should consider "demoting" the reference to that information in its search results. This is not censorship. Instead, this approach simply factors in the nature of the information itself in determining its relevance in response to search requests.

The primary problem with the application of a right to be forgotten in the United States is that any information posted online is considered speech, including compiled information from a search engine, and any effort to delete such information other than by the original poster implicates the speech of search engines. ${ }^{5}$ The First Amendment strongly protects such speech from any limitation. ${ }^{6}$ In addition, the Communications Decency Act $^{7}$ and its safe harbor immunize ${ }^{8}$ Internet service providers from liability with respect to speech of websites. ${ }^{9}$

In contrast, the EU interprets the online posting of information as the processing of "data" which is owned by the individual data

${ }^{3}$ Because of its overwhelming market share, see infra Part II.A, Google is the focus of this Article and is discussed interchangeably with search engines in general.

${ }^{4}$ See infra Part IV.A.

${ }^{5}$ This Article primarily concerns information posted by third parties, not a person's right to remove what they have posted themselves. Many have suggested that people have the right to remove information they have posted about themselves. See infra Part II.C. This Article also does not deal with the pernicious problem of data gathering by websites and search engines.

${ }^{6}$ See Hurley v. Irish-Am. Gay, Lesbian \& Bisexual Grp. of Boston, 515 U.S. 557,573 (1995) ("[O]ne important manifestation of the principle of free speech is that one who chooses to speak may also decide "what not to say." "). The Supreme Court's protection of the First Amendment has become even more robust recently. See Jane Yakowitz Bambauer, Is Data Speech?, 66 STAN. L. REV. 57 ("[T]he Court has been on a mission to apply the First Amendment broadly, and to interpret its exceptions narrowly.") (forthcoming 2013) (manuscript at 13).

${ }^{7} 47$ U.S.C. $\$ 230(2012)$.

${ }^{8} I d . \$ 230(\mathrm{c})(1)$.

${ }^{9}$ See infra Part III.B. 
subject. ${ }^{10}$ Under the EU's Data Protection Directive, such processing is subject to a host of restrictions. " Thus, under a system where an entity needs a purpose to gather personal information, and may use it only for the duration of that purpose, it is not far-fetched to imagine a requirement that particular information be deleted under certain circumstances, including when the data is no longer necessary for the original purpose. ${ }^{12}$

The Internet is likened to one huge street corner, where anyone with access is welcome to post at will on his or her virtual soapbox..$^{13}$ Search engines, however, control the streets and the prominence of any single soapbox. Search results are the primary determinant of how most individuals find information on the Internet. ${ }^{14}$ In addition, the average person who is harmed by information on the Internet does not necessarily seek to delete that information completely but to make it less easily accessible. ${ }^{15}$

${ }^{10}$ See Directive 95/46/EC of the European Parliament and of the Council of 24 October 1995 on the Protection of Individuals with Regard to the Processing of Personal Data and on the Free Movement of Such Data, 1995 O.J. (L 281) 31 ("Data Protection Directive"), available at http://eur-lex.europa.eu/LexUriServ/ LexUriServ.do?uri=CELEX:31995L0046:EN:HTML.

${ }^{11} I d$.

12 It is questionable whether the "right to be forgotten" in the EU extends to requiring search engines to delete third party material from their indices. See infra Part II.C (citing Google Spain SL and Google Inc. v. Agencia Espanola de Proteccion de Datos (AEPD), Case C 131/12, Par. 60,866 2013 WL 3489655 (June 25, 2013) (Opinion of Advocate General)).

${ }^{13}$ See Reno v. ACLU, 521 U.S. 844, 870 (1997) ("Through the use of chat rooms, any person with [an Internet connection] can become a town crier with a voice that resonates farther than it could from any soap box.").

${ }^{14}$ See Kristen Purcell et al., Pew Internet Project, Search Engine USE 2012, 3 (Mar. 9, 2012), available at http://pewinternet.org/Reports/2012/ Search-Engine-Use-2012.aspx ("On any given day in early 2012, more than half of adults using the internet use a search engine (59\%).").

${ }^{15}$ See Nate Anderson, "Algorithms Can Have Errors": One Man's Quest to Purge Horrific Pictures from his Google Results, ARS TECHNICA (Mar. 4, 2012, 5:00 PM), http://arstechnica.com/tech-policy/news/2012/03/algorithms-can-haveerrors-one-mans-quest-to-purge-horrific-pictures-from-his-google-results.ars?

clicked=related_right (discussing a Spanish camp owner who sued Google, asking that pictures from a long-ago event be "relocated"-not "deleted from the Net"-so that potential visitors would not see them immediately upon Googling the camp's name). 
Many people want to change the fact that harmful information is a prominent result of a Google search conducted by others-they may not even care that the information continues to be located on certain websites were it not for the ease with which that information is discoverable via searching. ${ }^{16}$ Google's response to those requests is that it cannot control the underlying websites, so removing information from its results is pointless. ${ }^{17}$ Instead, reducing the prominence of information in search results is the goal. $^{18}$

It is true that individuals have the ability to request that information be removed directly from host websites. But most people seeking removal directly from Google have already been unsuccessful in getting results from the webmaster. While Google states that it will honor court orders finding information violative of privacy rights, ${ }^{19}$ the very act of bringing suit renders the information "of interest to the public," justifying its prominence in search results. ${ }^{20}$

Google claims that it should do nothing because it cannot control content on websites, but the search results are themselves of paramount importance. This Article, therefore, proposes that Google use its procedure already in place to receive notification of harmful information and to "suppress" or "demote" that information in search results. This shifts the focus from deletion, or removal of information from the web as a whole, to suppression (recognition that the information is problematic and less relevant in response to search requests).

Precedent supports four categories of information that would justify a request that the information be suppressed: (1) the information is confidential and personal, such as a government-

\footnotetext{
${ }^{16}$ See Anderson, supra note 15.

${ }^{17}$ See infra Part IV.A.

${ }^{18}$ Anderson, supra note 15.

${ }^{19}$ See infra Part IV.A.

20 See Edward L. Carter, Recent Development: Argentina's Right to Be Forgotten, 27 EMORY INT'L L. REV. 23, 35-39 (2013) (describing why it is counter-productive to sue Google after it has refused a DMCA request, particularly when the party is seeking to suppress unflattering information about themselves).
} 
issued ID, a bank account number, or a credit card number; (2) the information relates to a minor; (3) the information is untrue or defamatory, or no longer "relevant" based on its age or subsequent events; or (4) the information is otherwise unduly harmful, e.g., likely to result in bullying or stalking. ${ }^{21}$ Google already gathers information from users that would allow it process such requests. In addition, the proposed standard for suppression is lower than requiring production of a court order of deletion. The requester must show that the information is more likely than not to fall within a protected category. If it does, Google should "demote" the information from the first page of a generic search result.

A primary benefit of this proposal is that, because it is suggestive only, it avoids the constitutional problem of mandating that search engines change their results. The proposal is less difficult to implement logistically than requiring removal of information, because it gives Google discretion in factoring the harmfulness of the information into its existing procedure-a practice it already undertakes. Finally, while the proposal falls short of requiring erasure like a broad interpretation of the EU's proposal, it addresses the primary concern of most people who seek such deletion-decreasing the prominence of harmful information in response to a search request.

Part II of the Article describes the problems created by the right to be forgotten as it relates to search engines specifically, and describes how search engines operate. Part III addresses the problems with recognizing a right to deletion in the United States. Part IV describes Google's current procedures for responding to requests for removal. Part $\mathrm{V}$ proposes that Google continue to allow users to identify certain categories of harmful information, and that it do more than refer those users to webmasters or courts. Part VI briefly concludes.

\footnotetext{
${ }^{21}$ See infra Part V.
} 


\section{GoOgle And OUR ONLine Memory}

\section{A. The Importance of Internet Search}

The Internet has unquestionably changed our lives. It has provided a worldwide dynamic forum for the exchange of ideas, interpersonal communication, and entertainment, all in semi-permanent form. Conversations or simple comments that would have taken place in person or on the telephone are stored in digital space as chats, texts, or emails. Billions of photographs are posted on social media ${ }^{22}$ and other online services (and often regretted later). While individuals post information on websites and social networks believing their audience to include only friends and family, many learn the hard way that their audience also includes employers and law enforcement. ${ }^{23}$ The growth of digital information impacts the life span of information as well as its vastness and ease of attainability. There is no more "practical obscurity" of information that might have been technically public but lost or much more difficult to retrieve. ${ }^{24}$

${ }^{22}$ Facebook currently stores 220 billion photographs, and 300 million new photographs are posted each day. See Robert Andrews, Facebook has 220 billion of your photos to put on ice, GIGAOM (Oct. 17, 2012, 1:47 AM), http:// gigaom.com/2012/10/17/facebook-has-220-billion-of-your-photos-to-put-onice/.

${ }^{23}$ See Patricia Sanchez Abril, Blurred Boundaries: Social Media Privacy and the Twenty-First-Century Employee, 49 AM. Bus. L. J. 63, 86 (2012) (citing CAREERBUILDER, http://www.careerbuilder.com/ (last visited Jan. 20, 2014)) ("One study recently found that forty-five percent of surveyed employers researched job candidates using online social networking sites." While "[m]ore than a third of employers in that survey also reported having found publicly available content on applicants' social media profiles that caused them not to hire the applicants."); see also Daniel Solove, A Taxonomy of Privacy, $154 \mathrm{U}$. PA. L. REV. 477, 487-90 (2006).

${ }^{24}$ U.S. Dep't of Justice v. Reporters Comm. for Freedom of the Press, 489 U.S. 749, 767 (1989) (FOIA incorporates a "practical obscurity" concept that "expressly recognizes that the passage of time may actually increase the privacy interest at stake when disclosure would revive in formation that was once public knowledge but has long since faded from memory."); U.S. DEP'T OF JUSTICE, GUIDE TO THE FREEDOM OF INFORMATION ACT 579 (2009), available at http://www.justice.gov/oip/ foia_guide09/exemption7c.pdf. 
Scholars have recently challenged the notion that digital information has a permanent life span, finding that digital information is more ephemeral than commonly believed. ${ }^{25}$ The phenomenon of "linkrot," "when URLs fail as access points to content," jeopardizes the certainty of website citations. ${ }^{26}$ In a substantial way, this only makes search engines more powerful because the content itself may still be online, just not in the original pathway. Search may be the only way information can be found in a long-term sense.

\section{Search Engine Usage}

Many Internet users have favorite websites saved on their computers as "bookmarks" and open links to those sites directly. Similarly, if a person knows a specific website address, she can visit it directly without first utilizing a search engine. "Surfing" the Internet often involves following internal links from website to website. ${ }^{27}$ For finding information that is not otherwise presented to the user as an address or active link, however, Google is the Internet. Search engines are crucial, enabling Internet users' perusal of an otherwise-unmanageable number of websites. ${ }^{28}$ In fact, a recent Pew Research Center survey found that seventy-three

${ }^{25}$ See Meg Leta Ambrose, It's About Time: Privacy, Information Life Cycles, and the Right to Be Forgotten, 16 STAN. TECH. L. REV. 369, 390-91 (2013) (noting studies finding the average URL has a lifespan of 44 days and an average webpage has a lifespan of 100 days).

${ }^{26} I d$. at 391.

27 See Wendy Boswell, Surf, About.com Computing: Web SearCH, http:// websearch.about.com/od/s/g/Surf.htm (last visited Jan. 21, 2014) ("The term surf, used in the context of 'surf the Web', refers to the practice of browsing through Websites: jumping from one link to the other, following items of interest, watching videos, and consuming all sorts of content; all on a variety of different sites.").

${ }^{28}$ See Frank Pasquale, Beyond Innovation and Competition: The Need for Qualified Transparency in Internet Intermediaries, 104 Nw. U. L. REV. 105, 105 (2010) [hereinafter Beyond Innovation] ("Internet intermediaries," like ISPs and search engines "govern online life."). 
percent of all Americans use search engines ${ }^{29}$ and, on average, use them more than once a day. ${ }^{30}$

While search engine usage has grown, the search engine of choice has narrowed. In 2012, eighty-three percent of U.S. searchers used Google most often; the nearest competitor is Yahoo with six percent. ${ }^{31}$ This too is an increase from the 2004 survey, which showed Google with forty-seven percent of the search market. ${ }^{32}$ When search usage is viewed worldwide, the gap between Google and other search engines is even larger. According to StatCounter Global Stats, Google has steadily held about ninety percent of the market share worldwide in $2013 .{ }^{33}$ Bing and Yahoo are the closest competitors with less than four percent each. ${ }^{34}$ And when the survey is narrowed to Europe, Google's lead is even greater: ninety-three percent of all searches are conducted using Google, compared with 2.4 percent for Bing, in second place. ${ }^{35}$

We cannot easily explain how search results are brought about because their methods are less than transparent, ${ }^{36}$ likened by many to a "black box." ${ }^{37}$ Google fiercely protects its patented algorithms, ${ }^{38}$

\footnotetext{
${ }^{29}$ PURCELL ET AL., supra note 14 , at 1.
}

${ }^{30} \mathrm{Id}$. The survey also showed that "[o]n any given day in early 2012, more than half of adults using the internet use a search engine (59\%). That is double the $30 \%$ of internet users who were using search engines on a typical day in 2004." Id.

${ }^{31}$ Id. at 4.

${ }^{32} \mathrm{Id}$.

${ }^{33}$ StatCounter, Top 5 Desktop, Tablet \& Console Search Engines from Oct. 2012 to Sept. 2013, STATCOUNTER GLOBAL STATS, http://gs.statcounter.com/ \#search engine-ww-monthly-201210-201309 (last visited Jan. 21, 2014).

${ }^{34} \mathrm{Id}$.

${ }^{35}$ StatCounter, Top 5 Desktop, Tablet \& Console Search Engines in Europe Oct. 2012 to Sept. 2013, STATCOUNTER GlOBAL STATS, http:/gs.statcounter. com/\#search engine-eu-monthly-201210-201309-bar (last visited Jan. 21, 2014).

${ }^{36}$ See Jonathan ZitTRAin, The FutURE OF THE INTERNET-AND How TO STOP IT 220 (Yale Univ. 2009) ("Correcting or identifying mistakes can be difficult if the systems are operated entirely by private parties and their ratings formulas are closely held trade secrets.").

${ }^{37}$ See Frank Pasquale, Restoring Transparency to Automated Authority, $9 \mathrm{~J}$. TEleCOMm. \& High TeCH. L. 235, 238 (2009) (quoting Ira Basen, The Algorithm Method: Programming Our Lives Away, GLOBE \& MAIL (Nov. 26, 2010), http:// www.theglobeandmail.com/technology/the-algorithm-method-programmingour-lives-away/article 131 5842/?page=all). 
a secrecy that obscures rankings which literally make or break reputations, careers, and fortunes. ${ }^{39}$ This lack of transparency compounds the problem: "a high ranking on search results can become a self-fulfilling prophecy of relevance, as the highestranked sites use revenue from visitors to improve the quality of their content." ${ }^{40}$ Similarly, entertaining but damaging links remain highly-ranked because of their very visibility.

\section{How Google Search Works}

Google begins its process by "crawling" or searching webpages using software robots, and indexing that data. ${ }^{41}$ Google's software discovers publicly available webpages, which it then organizes into an index, similar to the index of a book. ${ }^{42}$ When a user inputs a search query, Google's algorithms look up the search terms in its

${ }^{38}$ See ZiTTRAIN, supra note 36 , at 220 .

${ }^{39}$ See generally Frank Pasquale, Rankings, Reductionism, and Responsibility, 54 CLEV. ST. L. REV. 115 (2006) (illustrating influential powers of search engine rankings) [hereinafter Pasquale, Rankings]. The same author also notes:

Reputations are created or destroyed, highlighted or obscured, by search engines. Traditional restrictions on data and information flowsbe they in the form of privacy or intellectual property lawsinadequately constrain these important intermediaries. In considering the balance of power between search engines and those whom their actions affect, scholars have focused on either strengthening or weakening extant doctrines of copyright, trademark, contract, antitrust, and privacy law. However, a critical mass of doctrine in these fields (along with established patterns of consumer behavior and the advent of cloud computing) has freed up so much information that the law needs to be concerned not only with information aggregation, but also with rankings and evaluations that flow from it. We should be troubled when trade secrecy obscured the basis of these rankings.

Frank Pasquale, The Troubling Consequences of Trade Secret Protection of Search Engine Rankings, in THE LAW AND THEORY OF TRADE SECRECY: A HANDBOOK OF CONTEMPORARY RESEARCH 381, 402-03 (Rochelle C. Dreyfuss \& Katherine J. Strandburg eds., 2011).

${ }^{40}$ Pasquale, Restoring Transparency, supra note 37, at 237.

${ }^{41}$ Crawling \& Indexing, GOOGLE, http://www.google.com/intl/en/insidesearch/ howsearchworks/crawling-indexing.html (last visited Jan. 21, 2014) (including explanatory graphic).

42 See generally Viva R. Moffat, Regulating Search, 22 HARV. J.L. \& TECH. 475, 482-84 (2009) (providing background details as to how search engines operate and index materials). 
index and display the results. ${ }^{43}$ The algorithms use "over 200 signals" to determine which of the millions of webpages are most relevant to the user's query. ${ }^{44}$ The algorithms themselves are not released to the public, partly to avoid "gaming" or misuse of the system. ${ }^{45}$

\section{a. PageRank, Popularity, and "Quality"}

Many people view search results as mathematical and objective. ${ }^{46}$ Google has stated that "[t]here is no human involvement or manipulation of results, which is why users have come to trust Google as a source of objective information untainted by paid placement." ${ }^{47}$ Indeed, users consider Google search results to be fact. As one scholar states, "the more dominant a search engine is, the more its ranking is treated as (and becomes) a fact about the relevance, quality, and prominence of the ranked." 48

But in other contexts, namely when arguing that it has a First Amendment right not to be forced to change its results, Google states that its search results are not fact, but opinion. ${ }^{49}$ In addition, Google's own description of its process reveals the inherent subjectivity in how the results are compiled, as Google judges websites' "quality," "popularity," and "importance." Google's patented PageRank ${ }^{\mathrm{TM}}$ algorithm determines which websites are the

${ }^{43}$ Crawling \& Indexing, supra note 41.

${ }^{44} \mathrm{Id}$.

45 See Greg Lastowka, Google's Law, 73 BROOK. L. REV. 1327, 1346 (2008) ("[A] profitable business has grown up around the science of reverse engineering Google's algorithm and adapting business websites to please it. This practice is known as 'search engine optimization,' or 'SEO' for short."); Pasquale, Restoring Transparency, supra note 37, at 245 ("Google's secrecy about its website-ranking algorithm has provoked investigations in Europe.").

${ }^{46}$ See Eric Goldman, Deregulating Relevancy in Internet Trademark Law, 54 EMORY L.J. 507, 511 (2005).

47 Kinderstart.com LLC v. Google, Inc., No. C 06-2057 JF, 2006 WL 3246596, at *1 (N.D. Cal. Nov. 7, 2006) (citing Google "Technology Overview").

${ }^{48}$ Pasquale, Rankings, supra note 39 , at 125.

${ }^{49}$ See Search King, Inc. v. Google Tech., Inc., No. CIV-02-1457-M, 2003 WL 21464568, at 3 (W.D. Okla. May 27, 2003); see also James Grimmelmann, Speech Engines, 94 MiNN. L. REV. (forthcoming 2014) (manuscript at 4) (noting Google's own wavering on whether it is an editor or a "conduit"). 
best sources of information by counting "votes" of other sites. This "voting" is popularity represented by other sites" links to the page: "PageRank works by counting the number and quality of links to a page to determine a rough estimate of how important the website is. The underlying assumption is that more important websites are likely to receive more links from other websites." 51 Google touts the outcome of its search algorithm as presenting "only the most relevant results at the top of the page, sparing people from combing through the less relevant results below." 52 Indeed, no one combs through the "less relevant" results. Individuals have little capacity or willingness to delve further than the first page of results: "the first unpaid result is likely to get ten times the traffic as the tenth, and twice that of the second."

Google's algorithm is inherently subjective and gets "finessed" on a regular basis. ${ }^{54}$ Google recently stated that it changed its algorithm "to improve the user experience by catching and demoting low-quality sites that did not provide useful original content or otherwise add much value." ${ }^{155}$ The change simultaneously "provided better rankings for high-quality sites - sites with original content and information such as research, in-depth reports, thoughtful analysis and so on." 56 While there is no question that Google is good at what it does, ${ }^{57}$ it is also true that subjective judgment calls are inherent in its ranking process. ${ }^{58}$

${ }^{50}$ Ten Things We Know to Be True, GoOGLE, http://www.google.com/int//en/ about/company/philosophy/ (last visited Jan. 21, 2014).

${ }^{51}$ Facts About Google and Competition, GooGLE, http://www.google.com/ competition/howgooglesearchworks.html (last visited Jan. 21, 2014).

${ }^{52} I d$.

${ }_{53}^{53}$ Pasquale, Rankings, supra note 39, at 129.

${ }^{54}$ Split Second Search, GoOGLE, http://static.googleusercontent.com/media/ www.google.com/en/us/intl/en_us/insidesearch/howsearchworks/assets/searchIn fographic.pdf (last visited Feb. 5, 2014) ("Google finesses its ranking algorithm with over 500 improvements per year.").

${ }_{55}^{5}$ Facts About Google and Competition, supra note 51.

${ }^{56} \mathrm{Id}$.

${ }^{57}$ PURCELl ET AL., supra note 14, at 1 (finding that $91 \%$ of search engine users find the information they are seeking always or most of the time).

58 Searchmetrics, a search and social analytics company, has researched Google search results and describes webpage "quality" as the existence of text and images, although the correlation reduces after a certain number of 


\section{b. "Manual Control and the Human Element"}

Google acknowledges that it hand-edits results on occasion. For purposes of security, Google says it may "remov[e] pages from [its] index (including pages with credit card numbers and other personal information that can compromise security) ...."59 Google may also intervene for legal reasons, for instance when child sexual abuse imagery or copyright infringing material appear in the search results. ${ }^{60}$ And it "can make manual exceptions" when its algorithm "mistakenly catches websites" that should not have been identified ${ }^{61}$ Finally, Google uses both automated and manual action to remove spam, a category that includes attempts to "game" search results, such as use of "keyword stuffing." ${ }^{2}$ In addition, lawsuits and media stories tell of many instances in which Google has changed its results for a variety of reasons. ${ }^{63}$

\section{B. Search Results Have Results}

Search results impact our personal and professional lives. It is now common practice to "Google" everyone from a potential

characters. See Quality Links and Relevant Content Closely Linked with High Google Search Rankings Says New Research, SEARCHMETRICs (June 25, 2013), http://www.searchmetrics.com/en/searchmetrics/press/quality-links-and-

relevant-content-closely-linked $\%$. The study also found that search results are influenced by social signals like Facebook likes and shares, Twitter tweets, and - most influential of all-Google "plus ones." Id.

${ }^{59}$ Facts About Google and Competition, supra note 51.

${ }^{60}$ Id.

${ }^{61} I d$.

${ }^{62}$ Id. ("Google and other search engines publish and enforce guidelines to prevent unscrupulous actors from trying to game their way to the top of the results. For example, our guidelines state that websites should not repeat the same keyword over and over again on the page, a technique known as 'keyword stuffing.' While we use many automated ways of detecting these behaviors, we also take manual action to remove spam."). Google also chooses not to index certain pages, like Wikipedia "talk pages," which means those pages do not appear in any search results: "[Wikipedia a]rticles with unclear notability should not resort to deletion, but those that are clearly not notable should be deleted and useful material preserved on the talk pages, with are not indexed by Google." Id.

${ }^{63}$ See infra Part IV. 
employee or student to a potential date. ${ }^{64}$ Google has the power to make or break a person's personal or professional reputation, "to exclude content or make an overnight cultural sensation." ${ }^{65}$ The Court of Appeals for the District of Columbia Circuit has noted the way search impacts the attainability of information, stating "[i]f someone wants to know whether his neighbor or potential employee has been indicted for, convicted of, or pled guilty to a federal offense, he may well find out by simply entering a Google search for that person's name." ${ }^{66}$ Recent surveys found that $79 \%$ of employers, $20 \%$ of universities, and $40 \%$ of law schools search applicants online. ${ }^{67}$

The problem is that stories that are decades old, ${ }^{68}$ arrests that have been expunged, or lawsuits that have been found without merit may top search results based on a query of only a name. ${ }^{69}$ As Pasquale notes:

Rumors about a person's sexual experiences, health status, incompetence, or nastiness can percolate in blogs and message boards for years. Search engines can then increase the salience of such information, making a single mistake or scandal the dominant image of a person online. Even more chillingly, the subject of such innuendo may never know its influence on important decisionmakers. ${ }^{70}$

${ }^{64}$ See Meg Leta Ambrose, You Are What Google Says You Are: The Right to Be Forgotten and Information Stewardship, 17 INT'L REV. OF INFO. ETHICS 21, 22 (2012), available at http://ssrn.com/abstract=2154353 ("We size each other (and ourselves) up through online search engines. Universities, employers, and potential romantic partners search users to discover what has not been included in the initial disclosure."); see also Meg Leta Ambrose, Seeking Digital Redemption: The Future of Forgiveness in the Internet Age, 29 SANTA CLARA COMPUTER \& HIGH TECH. L.J. 99, 152 (2012) ("Currently, 79\% of employers, $20 \%$ of universities, and $40 \%$ of law schools search applicants online.").

${ }^{65}$ Alex W. Cannon, Regulating Adwords: Consumer Protection in a Market Where the Commodity is Speech, 39 SETON HALL L. REV. 291, 296 (2009).

${ }^{66}$ ACLU v. U.S. Dep't of Justice, 655 F.3d 1, 10 (D.C. Cir. 2011).

${ }^{67}$ Ambrose, Seeking Digital Redemption, supra note 64, at 152.

${ }^{68}$ See Anderson, supra note 15 (describing a camp owner in Spain haunted by pictures of an accident that took place there 30 years earlier but that were displayed prominently in Google searches).

${ }^{69}$ See Pasquale, Beyond Innovation, supra note 28, at 113 (describing "automated reputation creation").

${ }^{70}$ Id. (footnotes omitted). 
Google is telling searchers that the most relevant thing about a particular person is a fact the person herself would not consider relevant at all. ${ }^{71}$ Because Google bases its search result rankings on the number of links to websites, ${ }^{72}$ a vicious cycle emerges $:^{73}$ the public is scintillated and entertained by the salacious or at least by the negative; therefore, negative stories top search results, making them more easily found to be viewed by others. ${ }^{74}$ Search results also enable identity theft, mistaken identity, ${ }^{75}$ false light comparisons, ${ }^{76}$ stalking, and bullying. ${ }^{77}$

One teacher in Canada has experienced first-hand the implications Google searching may have on securing a job in the face of harmful Internet postings. ${ }^{78}$ Lee David Clayworth was cyberstalked by an ex-girlfriend who posted defamatory comments about him and private photos. ${ }^{79} \mathrm{He}$ has been unsuccessful in applying for new teaching positions, and believes "prospective employers are turned off by the web postings." ${ }^{80}$ Clayworth describes the relentless comments and photos: "I did a Google search of my name and I saw profiles listed saying ... I am a

${ }^{71}$ Professor Frank Pasquale terms these harms from unwanted references in search results as "inclusion harm." Pasquale, Rankings, supra note 39, at 135-37. Less germane to the right to be forgotten discussed herein but equally pernicious is "exclusion harm," or the forms of bias introduced by search engines via the removal of websites from the search engine index or great reduction of the website's ranking, the refusal to run prominent advertisements from certain websites, and the preferential indexing or ranking of paying websites. Id. at 137-38.

${ }^{72}$ See Jennifer A. Chandler, A Right to Reach an Audience: An Approach to Intermediary Bias on the Internet, 35 HOFSTRA L. REV. 1095, 1108 (2006-07).

73 Chandler discusses this practice from a more economic perspective, referring to search's promotion of a "bias toward majoritarian interests and sites with the economic resources to purchase advertising." Id. at 1109.

${ }^{74}$ See infra Part II.D.

${ }^{75}$ See Pasquale, Beyond Innovation, supra note 28, at 113-15.

${ }^{76}$ See Stayart v. Google Inc., 710 F.3d 719, 723 (7th Cir. 2013).

${ }^{77}$ See infra Part V.A.

${ }^{78}$ Kathy Tomlinson, Teacher 'Powerless' to Stop Ex-Girlfriend's Cyberstalking, CBC News (May 6, 2013, 2:32 AM), http://www.cbc.ca/news/canada/british-col umbia/teacher-powerless-to-stop-ex-girlfriend-s-cyberstalking-

1.1314610 ?cmp=rss.

${ }^{79} \mathrm{Id}$. 
psychopath, I am a child molester, a pedophile, I am involved with my students and so on." ${ }^{\text {"81 }}$ While Clayworth was able to obtain a court order requiring search engine providers Google, Yahoo, and Bing to block his name from being searchable, he has not received any positive response from those search engines. ${ }^{82}$

Scholars have noted the power wielded by search engines and the danger posed by unregulated search. Pasquale argues that "some accountability for search engine results is increasingly necessary as they become the primary portal for net users." ${ }^{83}$ Tim Wu likens Google to the telephone switches of old, which-along with a few other carriers-"are in a unique position to control speech in America." ${ }^{84}$ Because of the importance of search engines, and because the average person who is harmed by information on the Internet seeks not to delete that information but to make it less accessible, this Article shifts the focus from deletion of online information to demotion of that information in search results. Google has the unique power of filtering the whole of the Internet for its billions of users. ${ }^{85}$ It tells those users what is "relevant" to their search, based on its own algorithm, and it changes that algorithm or even hand-edits results on occasion.

\section{The Right to Be Forgotten in the EU}

The EU has approached the problem of harmful online information by proposing the Internet version of the "right to be forgotten."

${ }^{81} I d$.

${ }^{82} I d$.

${ }^{84}$ Pasquale, Rankings, supra note 39, at 117.

${ }^{84}$ Tim Wu, Is Filtering Censorship? The Second Free Speech Tradition, in Constitution 3.0: Freedom AND TeChNological Change 83, 96 (Jeffrey Rosen \& Benjamin Wittes eds., 2011).

${ }^{85}$ See comScore Releases January 2013 U.S. Search Engine Rankings, COMSCORE (Feb. 13, 2013), http://www.comscore.com/Insights/Press_Releases/ 2013/2/comScore_Releases_January_2013_U.S._Search_Engine_Rankings (finding 13.1 billion searches conducted on Google worldwide in January 2013); see also PURCELL ET AL., supra note 14, at 1 ( $83 \%$ of Americans use Google).

${ }^{86}$ Reding, supra note 2, at 5 . For general background on the right to be forgotten, see Werro, supra note 1 and Bennett, supra note 1. 
erasure of information to which the person objects. ${ }^{87}$ The EU Data Protection Directive of 1995 already allows subjects the right to have their data retained only as long as necessary for processing, and courts have, in the past, enforced the right on the part of convicted murderers since rehabilitated. ${ }^{88}$ Now, the EU is considering the right to be forgotten as a way "to give people control over their data" and "withdraw their consent to the processing of the personal data they have given out themselves." 89

Not surprisingly, Google is the target of many of the litigants seeking to enforce a right to delete. ${ }^{90}$ For example, Bettina Wulff, the ex-wife of a former German president, sued Google because its "auto-complete" function suggests terms like "escort," "prostitute,"

${ }^{87}$ Under Proposed Article 17, individuals could assert right to erasure of information in the possession of other parties if the information is no longer necessary for the purposes for which it was originally collected, the data subject no longer consents to the retention of the information or the consent has expired; the data subject objects to the processing of the information, and the processing of the data does not comply with other sections of the regulation. Proposal for a Regulation of the European Parliament and the Council on the Protection of Individuals with Regard to the Processing of Personal Data and on the Free Movement of Such Data (General Data Protection Regulation), at 51, COM (2012) 11 final (Jan. 25, 2012). There is an exemption for personal data that is necessary for exercising the right to freedom of expression. Id. at 52. The Proposed Data Protection Regulation must be reviewed by the European Parliament and twenty-seven EU States, and is expected to become law in 2014.

${ }^{88}$ German courts ordered certain publishers to remove references to a convicted murderer's past after he had been released from prison. See Jasmine E. McNealy, The Emerging Conflict Between Newsworthiness and the Right to be Forgotten, 39 N. KY. L. REV. 119, 120 (2012).

${ }^{89}$ Viviane Reding, Vice President, Eur. Comm'n, The EU Data Protection Reform 2012: Making Europe the Standard Setter for Modern Data Protection Rules in the Digital Age (Dec. 26, 2011), available at http://europa.eu/ $\mathrm{rapid} / \mathrm{press}-$ release_SPEECH-12-26_en.htm. The right to be forgotten itself has a complicated history; see Napoleon Xanthoulis, Conceptualising a Right to Oblivion in the Digital World: A Human Rights-Based Approach at 32 (May 22, 2012), available at http://ssm.com/abstract $=2064503$ ("I have tried to show that there seems to be no universal agreement, either on the substantial constituting elements of the right to oblivion in the digital worid, or on the term that should be used to describe it . . . My view has been that oblivion has proven under certain circumstances to be a necessity, or in different terms, an instrument, to safeguard human well-being.").

${ }^{90}$ See supra Part II.B (describing Google's market share). 
and "red light district" when her name is searched. ${ }^{91}$ Mrs. Wulff denies she has ever worked as a prostitute and blames rumors on political opposition to her husband. ${ }^{92}$ She has spent years fighting the stories, obtaining 34 successful cease-and-desist orders, and is now suing Google for its search term suggestions, which Google defends as "algorithmically generated" and based on terms previously entered by Google users. ${ }^{93}$

One well-known suit against Google and Yahoo was brought by the Argentine pop star Virginia Da Cunha, who fought to remove photographs of herself that were posted by others to sexrelated websites. ${ }^{94}$ She won at the trial level but lost on appeal when the court found that the search engines were not responsible..$^{95}$ In a recent law review article, Edward Carter notes that there are 200 similar cases pending in Argentina courts and that many actresses, models, and athletes have been successful in obtaining the removal of Internet search results and links to photos. However, these victories have been based on theories of copyright, privacy, and data protection rather than the right to be forgotten. ${ }^{96}$

Courts in individual countries have ordered Google to take down certain information, ${ }^{97}$ but it is not clear yet whether those decisions will be upheld by EU courts. Spain's regulators argued in the European Court of Justice that "Google must delete from its search results any information that would potentially hurt a person's privacy," while Google argued that "it doesn't have a responsibility to wipe search results, and doing so could create a

${ }^{91}$ Google Sued Over Bettina Wulff Search Results, BBC NEwS TECH. (Sept. 10, 2012, 1:03 PM), http://www.bbc.co.uk/news/technology-19542938.

${ }_{92} \mathrm{Id}$

${ }^{93} \mathrm{Id}$.

${ }^{94}$ See Carter, supra note 20, at 29-30.

${ }^{95}$ See id.

${ }^{96}$ See id. at 34 .

${ }^{97}$ See T.C. Sottek, Spain Challenges Google with 'Right to Be Forgotten' in EU, THE Verge (Mar. 5, 2012, 11:45 AM), http://www.theverge.com/2012/3/5/ 2846192/google-right-to-be-forgotten-Spain-EU-court (discussing cases in Spain, one in which a man is contesting the repeated appearance of an old notice about his home's repossession in Google News, even though he had resolved the dispute years earlier). 
scenario where other cases are brought before it to remove data." 98 The European Court of Justice's Advocate General issued an opinion stating that search engines are not responsible for personal information appearing on web pages they process and that "the Directive does not provide for a general right to be forgotten in the sense that a data subject is entitled to restrict or terminate dissemination of personal data that he considers to be harmful or contrary to his interests." 99 The 1995 version of the Directive applies, but the EU's Advocate General expressed his opinion that the revised provision may not change this result. ${ }^{100}$

Other European courts seem to be growing aware of the impracticability of a broad right to erasure. The Italian Appeals Court overturned the convictions of two Google executives for refusal to take down a video on Google's YouTube, acknowledging that while the Internet requires oversight, forcing a web company to monitor all content it hosts would risk creating a climate of censorship. ${ }^{101}$ Google "could not be required to exercise preventive control" of the content the company hosts because of the sheer volume of such information. ${ }^{102}$ At a recent conference, Google's privacy policy counsel in Brussels stated that the overall objective

${ }^{98}$ Don Reisinger, Google spars with Spain over data privacy, CNET (Feb. 26, 2013, 10:12 AM), http://www.news.cnet.com/8301-1009_3-57571351-83/googlespars- with-spain-over-data-privacy.

${ }^{99}$ Op. of Advocate Gen. Jääskinen Google Spain, SL v. Agencia Española de Protección de Datos, Case C-131/12 at | 108 (June 25, 2013), available at http://curia.europa.eu/juris/document/document.jsf?text $=\&$ docid $=138782 \&$ pagel ndex $=0$ \&doclang $=E N \&$ mode $=$ req $\&$ dir $=\&$ occ $=$ first $\&$ part $=1 \&$ cid $=362663$.

${ }^{100}$ See id. The opinion finds that Google and other search engines may be forced to remove or block websites when those sites include information that is libelous, defamatory, or violative of intellectual property rights. Press Release, Court of Justice of the European Union, Advocate General Jääskinen considers that search engine service providers are not responsible, on the basis of the Data Protection Directive, for personal data appearing on web pages they process (June 25, 2013), available at http://curia.europa.eu/jcms/upload/docs/ application/pdf/2013-06/cp130077en.pdf.

101 See Eric J. Lyman, Italian Appeals Court Reveals Reasoning Behind Overturned Google Exec Convictions, BloomberG EleC. COM. \& LAW ReP., Mar. 4, 2013 (discussing In re Fleischer, App. Milan, No. 4889/2010, released $2 / 27 / 13)$.

${ }^{102}$ See id. 
of the right to be forgotten article was a positive one and that Google already complies with the proposal to give users the ability to object to their data being held. ${ }^{103} \mathrm{He}$, however, expressed concern with the company's ability to delete data placed on a third party site with little control over the data. ${ }^{104}$

\section{Suppression: A Rising Demand in the United States}

There was a massive outcry in the United States when the EU announced its proposal of an Internet right to be forgotten. ${ }^{105}$ The media raised the specter of online censorship, of an "Internet Delete Button [that] Would Create Chaos." ${ }^{106}$ Scholars like Jennifer Chandler argue that " $[\mathrm{t}] \mathrm{h}$ right to be forgotten transforms Facebook, Google, Reddit, and Twitter into censors, charged with evaluating whether a particular bit of expression has artistic or journalistic merit or otherwise constitutes free expression." 107 But here too a growing number of people have sought to take down or minimize information on the Internet, including bringing lawsuits against search engines, and all signs point to this increasing. ${ }^{108}$

There is political support in the United States for a person's right to access the personal information about her that is held by an online entity, and there is support for users'-in particular, minors'

103 See Kelly Fiveash, Google Exec Questions Reding's 'Right to be Forgotten' Pledge, THE REGISTER (Jan. 26, 2012), http://www.theregister.co. uk/2012/01/26/google_exec_criticises_right_to_be_forgotten_proposal/.

${ }^{104}$ See id.

105 See, e.g., Peter Grad, Tech 3.0, What if we all had an erase button?, NORTHJERSEY.COM (May 20, 2011), http://www.northjersey.com/news/1222812 09 Internet_delete_button_would_create_chaos.html; Kevin J. O'Brien, Silicon Valley Companies Lobbying Against Europe's Privacy Proposals, N.Y. TIMES (Jan. 25, 2013), http://www.nytimes.com/2013/01/26/technology/eu-privacy-pro posal-lays-bare-differences-with-us.html?_r=1\&.

${ }^{106}$ Grad, supra note 105.

107 Anupam Chander \& Uyen P. Le, The Free Speech Foundations of Cyberlaw (U.C. Davis Legal Studies Research Paper No. 351, Aug. 23, 2013), available at $\mathrm{http}: / / \mathrm{ssrn}$.com/abstract $=2320124$.

${ }^{108}$ Ninety-four percent of parents and ninety-four percent of adults believe that an individual should have the right after a certain amount of time to have personal information held by search engines, social networking sites, or marketing companies deleted. Ambrose, You Are What Google Says You Are, supra note 64, at 22 . 
right to delete information posted by the user herself. One month after the European Commission issued its draft data regulation, the White House issued its "Consumer Privacy Bill of Rights," which aimed to give consumers increased access to and control over their online personal information. ${ }^{109}$ Legislation was recently introduced in the House of Representatives that would provide for deletion of personal information from applications on mobile devices. ${ }^{110}$ The Governor of California recently signed a new law that gives minors the right to erase posts they have made to online sites such as Facebook and Twitter. ${ }^{111}$

In addition, the government and individual citizens are requesting deletion of online content. Google's Transparency Report ${ }^{112}$ reveals that requests from the United States for removal of content for privacy-related reasons actually outnumber those of the average EU country. ${ }^{113}$ The United States "sought to remove

109 Consumer Data Privacy in a Networked World: A Framework for Protecting Privacy and Promoting Innovation in the Global Digital Economy, THE WHITE HOUSE (Feb. 2012), http://www.whitehouse.gov/sites/default/ files/privacy-final.pdf; see Robert G. Larson III, Forgetting the First Amendment: How Obscurity-Based Privacy and a Right to Be Forgotten Are Incompatible with Free Speech, 18 COMM. L. \& POL'Y 91, 92 (2013).

${ }^{110}$ See Application Privacy, Protection, and Security Act, H.R. 1913, 113th Cong. (2013) ("The developer of a mobile application shall- (1) provide a user of the application with a means of - ... (B) requesting the developer- . . (ii) at the option of the user, either- (I) to the extent practicable, to delete any personal data collected by the application that is stored by the developer; or (II) to refrain from any further use or sharing of such data.").

111 See California Enacts Poor Man's Right to Be Forgotten, InFoSECURITY (Sept. 24, 2013), http://www.infosecurity-magazine.com/view/34693/californiaenacts-poor-mans-right-to-be-forgotten/; S.B. 568, 2013 Leg., Reg. Sess. (Cal. 2013).

${ }^{112}$ Google issues a Transparency Report that describes the requests it receives from governments around the world for removal of information from all Google products - its search engine as well as YouTube and other Google-owned services. The report describes requests received from copyright owners and governments, but not from individuals. See Transparency Report, GoOGLE, http://www.google.com/transparencyreport/removals/government/US/ (last visited Jan. 22, 2014).

${ }^{113}$ See gęnerally Jane R. Bambauer \& Derek E. Bambauer, Vanished, 18 VA. J.L. \& TECH. 137 (2013). The Bambauers compared the rates of takedown requests 
the second-highest number (on a per million Google user basis) of items related to defamation (70.26), after Germany (93.80)." $" 14$ The number of take-down requests from the United States increased for each reporting period. The number of requests based on defamation has increased from 39 in the period ending in December 2010, to 55 in the first half of 2011,117 in the second half of 2011, 209 in the first half of 2012, and 262 in the second half of 2012. ${ }^{115}$ U.S. requests for removal based on "privacy and security" have also increased, from 15 in the latter half of 2010 to 64 in the first half of 2012 and 59 in the second half of 2012. ${ }^{116}$

Professors Derek and Jane Bambauer point out that Google's transparency data is inconsistent with the notion that the United States opposes censorship while Europe prefers to protect privacy: "Google's transparency data rewrites standard assumptions about Internet censorship: America tries to take down more content than expected, some European countries less, and several emerging economies lead the way." "17 The United States asked Google to remove a number of items during the survey period comparable to requests by the United Kingdom and Germany. ${ }^{118}$ "This result is in tension with America's reputation-partly self-proclaimed-as a defender of free expression on-line." 19

In addition, there have been a number of lawsuits brought against Google by individuals seeking removal or alteration of information in search results. In one example, an individual brought suit complaining that a Google search for his name led to a web page that, he says, accuses him incorrectly of wrongdoing. ${ }^{120}$

from given countries by calculating the number of such requests per million Google users in the study period. See id. at 144-45.

${ }^{114}$ Id. at 112 .

115 See Transparency Report, supra note 112.

${ }^{116} \mathrm{Id}$.

${ }^{117}$ Bambauer \& Bambauer, supra note 113, at 151 .

118 See id. at 149.

${ }^{119} I d$. The Bambauers also note that " $[\mathrm{w}]$ hile some of the requests are based on intellectual property infringement, which the United States typically views as unrelated to free speech concerns, a surprising number relate to defamation and to individual privacy/security." Id.

120 See Ted Frank, Mark Maughan sues Google over search engine results, OVERLAWYERED (Mar. 28, 2004), https://www.overlawyered.com/2004/03/mark 
Other plaintiffs have sought damages based on Google's failure to delete allegedly libelous statements. ${ }^{21}$ In some instances the harmful statements are made anonymously. ${ }^{122}$

Sportscaster Erin Andrews tried for years to have removed from the Internet a video of her naked in a hotel room that was filmed and uploaded by a stalker. ${ }^{123}$ Andrews said the video is "the second thing you see" when you Google her name, which she believes constitutes cyberbullying: "[I]t's pretty ironic because Google is promoting a campaign to fight bullying that literally makes you want to cry [. . . but] at the same time, Google is helping people get to my video. I consider that cyberbullying." 124

Beverly Stayart sued because a search of her name in Google triggers sponsored links, ads, and related searches to drugs like

maughan_sues_google_over.html; see also JOHN BATTELLE, THE SEARCH: How GoOgle AND ITS RIVAls REwRote THE RULES OF Business AND TRANSFormed OUR CULTURE 191 (Portfolio Trade, 2005).

121 See, e.g., Supplementmarket.com v. Google, No. 09-43056, 2010 WL 6309991, *1 (Pa. Commw. Ct. P1. July 26, 2010).

${ }^{122}$ See Mmubango v. Google, Inc., No. 12-1300, 2013 WL 664231, *1 (E.D. Pa. Feb. 22, 2013); see also Stephanie Rosenbloom, Loosing Google's Lock on the Past, N.Y. Times (June 2, 2005), http://www.nytimes.com/2005/06/02/ fashion/thursdaystyles/02GOOGLE.html?adxnnl=1 \&pagewanted=all\&adxnnlx= 1390065648-UZ8kclbE0dp8GVOrKCK/0g\&_ $=0$ (describing an Oregon woman's suit against Yahoo for not removing photographs of her, emails, and other personal information posted by an ex-boyfriend without permission); McNealy, supra note 88, at 1 (discussing case brought by father of now-deceased university student in 2010 when the editor of the Daily Californian refused to erase or alter websites that described the son's unruly behavior at an adult club and his subsequent dismissal from the university football team four years prior).

${ }^{123}$ See Abigail Pesta, The Haunting of Erin Andrews, MARIE CLAIRE (July 13, 2011), http://www.marieclaire.com/celebrity-lifestyle/celebrities/erin-andrewsinterview. Andrews is seeking to obtain the copyright to the video filmed of her by a stalker so that she can try to remove it from the Internet. See id.

${ }^{124} \mathrm{Id}$; see also Jeffrey Rosen, The End of Forgetting, N.Y. TIMES MAGAZINE, July 26, 2013, at 37 (noting that "two recent studies challenge the conventional wisdom that young people have no qualms about having their entire lives shared and preserved online forever. A University of California, Berkeley, study released in April found that large majorities of people between 18 and 22 said there should be laws that require Websites to delete all stored information about individuals ( 88 percent) and that give people the right to know all the information Websites know about them (62 percent)-percentages that mirrored the privacy views of older adults."). 
Levitra, a treatment for male erectile dysfunction. ${ }^{125}$ The plaintiff in Nieman v. Versuslaw, ${ }^{126}$ who had been involved in litigation against his former employer, sued when he discovered that certain Internet websites were "linking copies of information related to the litigation to [Plaintiff's] name, such that an internet browser search for his name would provide immediate results that referenced the filings or rulings in his litigation." 27 While some claims for removal have more merit than others, none have been successful legally.

\section{U.S. LAW'S Protection Of SEARCh ENGINES}

Under U.S. law there is little recourse for an individual seeking to challenge results posted by a search engine. Search results are likely to constitute speech under the Supreme Court's broad precedents. ${ }^{128}$ Furthermore, where speech is subject to regulation, search engines are essentially immune from liability. ${ }^{129}$

\section{A. The First Amendment}

The First Amendment protects speech from government restriction, with narrow exceptions for categories like obscenity and "fighting words." 130 There is less constitutional protection given to speech in an intermediate category that includes commercial speech. ${ }^{131}$ While there are cogent arguments that some search engine results constitute commercial speech, ${ }^{132}$ it is likely

\footnotetext{
${ }^{125}$ See Stayart v. Google Inc., 710 F.3d 719, 720-21 (7th Cir. 2013).

${ }^{126}$ No. 12-3104, 2012 WL 3201935, No. 12-3104 (C.D. Ill. June 13, 2012).

${ }^{127} \mathrm{Id}$. at *1.

128 The Supreme Court's recent jurisdiction defines speech broadly. See Bambauer, supra note 6 , at 13 ("[T] First Amendment broadly, and to interpret its exceptions narrowly.").

${ }^{129}$ See infra Part III.B.

${ }^{130}$ See Miller v. California, 413 U.S. 15, 36 (1973).

${ }^{131}$ Cent. Hudson Gas \& Electric Corp. v. Pub. Serv. Comm'n of N.Y., 447 U.S. 557 (1980) (holding a restriction on speech that proposes a commercial transaction must be necessary to further a substantial government interest).

132 See Cannon, supra note 65, at 316-18 (2009) (arguing that AdWords results are commercial speech subject to regulation). But see Grimmelmann, supra note 49 (manuscript at 32) ("Search results are not themselves commercial speech.").
} 
that any requirement in the United States that Google delete search results would violate the First Amendment. ${ }^{133}$ When Google presents a list of website links and information in response to a user's search query, Google is in effect saying "these are the relevant search results." This is speech in the form of opinion protected against abridgement by the government. ${ }^{134}$ The fact that it takes place on the Internet does not diminish its protection. ${ }^{135}$

The few courts that have addressed the issue agree. In Search King v. Google ${ }^{136}$ the District Court for the Western District of Oklahoma dismissed Search King's claims against Google for allegedly manipulating its PageRank results to downgrade Search King because it was competing with Google for ad revenue. The court agreed with Google that Search King's claim for tortious interference with contractual relations was subject to dismissal because its search engine results are protected speech under the First Amendment: "[U]nder Oklahoma law, protected speech-in this case, PageRank's - cannot give rise to a claim for tortious interference with contractual relations because it cannot be

${ }^{133}$ See Part III.A. One argument that has been advanced unsuccessfully is that in cases where Google has allegedly manipulated its search results, those results are provably false. See Search King Inc. v. Google Tech., Inc., No. CIV-021457-M, 2003 WL 21464568, at *2 (W.D. Okla. May 27, 2003) (citing Milkovich v. Lorain Journal Co., 497 U.S. 1, 20 (1990)) ("[A] statement of opinion relating to matters of public concern which does not contain a provably false factual connotation will receive full constitutional protection."). That court found instead that search results are constitutionally protected opinion. Id.; see also Eugene Volokh \& Donald M. Falk, Google First Amendment Protection for Search Engine Search Results, 8 J.L. ECON. \& POL'Y 883, 884 (2012); Grimmelmann, supra note 49 (manuscript at 20).

${ }^{134}$ U.S. ConST. amend. I. See United States v. Stevens, 130 S. Ct. 1577, 1584 (2010) (citing Ashcroft v. ACLU, 535 U.S. 564, 573 (2002) ("As a general matter, the First Amendment means that government has no power to restrict expression because of its message, its ideas, its subject matter, or its content.")). Although the text of the First Amendment only prohibits Congress from enacting laws that abridge the freedom of speech, the Fourteenth Amendment makes this limitation applicable to the States as well. See Gitlow v. New York, 268 U.S. 652, 666 (1925).

${ }^{135}$ See Reno v. ACLU, 521 U.S. 844, 885 (1997) (holding speech on the Internet receives the highest level of First Amendment protection).

${ }^{136}$ No. CIV-02-1457-M, 2003 WL 21464568 (W.D. Okla. May 27, 2003). 
considered wrongful, even if the speech is motivated by hatred or ill will." 137

Similarly, in Langdon v. Google, ${ }^{138}$ the District Court for the District of Delaware dismissed claims by the plaintiff alleging that several search engines wrongfully refused to run its advertisements based on their political content, and removed his websites from Google's search results. ${ }^{139}$ The court agreed with Google that requiring it to run the plaintiff's ads prominently or to rank his websites more favorably would "compel [Google] to speak in a manner deemed appropriate by Plaintiff and would prevent Google from speaking in ways that Plaintiff dislikes," thus violating the First Amendment. ${ }^{140}$ The plaintiff's own First Amendment rights were not violated, however, because the defendants were private companies. $^{141}$

In Nieman $v$. Versuslaw ${ }^{142}$ the court dismissed plaintiff's claims based in part on First Amendment grounds: "All of Plaintiff's allegations rest on the premise that Defendants' websites provide links to information that is in the public record." Because the First Amendment "greatly circumscribes the right even of a private figure to obtain damages for the publication of newsworthy facts about him, even when they are facts of a kind that people want very much to conceal," plaintiff's claims were subject to dismissal. ${ }^{143}$ Scholars and commentators also find that the

${ }^{137}$ Search King, 2003 WL 21464568 at *4.

${ }^{138}$ Langdon v. Google, Inc., 474 F. Supp. $2 d 622$ (D. Del. 2007).

${ }^{139} I d$. at $630-31$.

${ }^{140}$ Id. at 630 (citing Miami Herald Publishing Co. v. Tornillo, 418 U.S. 241 (1974) (forcing newspapers to print candidates' replies to editorials is an impermissible burden on editorial control and judgment)); see Sinn v. The Daily Nebraskan, 829 F.2d 662 (8th Cir. 1987) (holding a university's newspaper's rejection of roommate advertisements in which advertisers stated their gay or lesbian orientation was a constitutionally protected editorial decision); Associates \& Aldrich Co. v. Times Mirror Co., 440 F.2d 133 (9th Cir. 1971) (holding a court cannot compel the publisher of a private daily newspaper to accept and print advertising in the exact form submitted based upon the freedom to exercise subjective editorial discretion in rejecting a proffered article).

${ }^{141}$ Langdon, 474 F. Supp. 2d at 631.

${ }^{142}$ No. 12-3.104, 2012 WL 3201931 (C.D. Ill. Aug. 3, 2012).

${ }^{143}$ Id. at $* 7$ (quoting Haynes v. Alred A. Knopf, Inc., 8 F.3d 1222, 1232 (7th Cir. 1993)). 
enforcement of a right to delete information online in the United States would violate the First Amendment. ${ }^{144}$

\section{B. Section 230 of the Communications Decency Act}

If Google's search results are speech protected by the First Amendment, the only liability that would be constitutionally permitted against it for harmful information in its search results, other than for intellectual property violations, ${ }^{145}$ is for publication of "obscenity, defamation, fraud, incitement, and speech integral to criminal conduct." 146 Here, however, Google is immunized from liability by an Act of Congress. Section 230 of the Communications Decency Act ("CDA") provides, in part, that (1) "no provider or user of an interactive computer service shall be treated as the publisher or speaker of any information provided by another information content provider" and (2) "no cause of action may be brought and no liability may be imposed under any State or local rule that is inconsistent with this section." 147

Section 230 of the CDA has been construed as prohibiting a lawsuit against an interactive computer service for "the exercise of editorial discretion over internet content and editorial decisions regarding screening and deletion of content from their services."148 In Langdon, the court found not only that search results constituted speech under the First Amendment, but that "[s]ection 230 provides Google, Yahoo, and Microsoft immunity for their editorial decisions regarding screening and deletion from their network." "49

${ }^{144}$ McNealy, supra note 88, at 1; Werro, supra note 1, at 285-300; Robert Kirk Walker, Forcing Forgetfulness: Data Privacy, Free Speech, and the "Right to be Forgotten," Working Paper Series (2012), available at http://ssrn.com/ abstract $=2017967$.

${ }^{145}$ Here, too, litigants against Google have been unsuccessful.

${ }^{146}$ United States v. Stevens, 130 S. Ct. 1577,1580 (2010).

14747 U.S.C. $\S 230(\mathrm{c})(1),(\mathrm{e})(3)(2012)$.

${ }^{148}$ Langdon v. Google, Inc., 474 F. Supp. 2d 622, 630 (D. Del. 2007).

${ }^{149}$ Id. at 631; see also Nieman v. Versuslaw, No. 12-3104, 2012 WL 3201931, at *2 (C.D. Ill. Aug. 3, 2012) (finding that Section 230 of the CDA barred many of plaintiff's claims). 
Two Pennsylvania courts have also dismissed claims against Google based on the CDA. The plaintiff in Supplementmarket.com, Inc. v. Google $e^{150}$ sought damages based on Google's failure to delete allegedly libelous statements. ${ }^{151}$ The court found that Google is an information content provider under the Act, and that section 230 , therefore, "expressly preempts state law insofar as plaintiff could maintain any cause of action against Google based on Google's role as a publisher or speaker of information."152 Similarly, the Eastern District Court of Pennsylvania dismissed claims against Google brought by an individual who complained of anonymous, derogatory statements made on another website but accessible based on searching Google:

The Court holds that the CDA immunizes the defendant against the plaintiff's allegations. Google cannot be held liable for state law defamation on the facts that it "decided" to publish a third party's statements, which has been identified by the Third Circuit as a traditional editorial function. In the same vein, Google cannot be held liable for failing to withdraw this statement once it has been published. $^{153}$

Liability against search engine providers for the harmful content in search results is, thus, clearly barred.

\section{Privacy Torts}

Litigants have also tried, unsuccessfully, to assert privacy law claims against Google. In one line of case law, Google is sued for its suggestions rather than for the webpages in its search results. A plaintiff alleged that Google violated her right of publicity by using her name to trigger sponsored links, ads, and other searches related to treatments for male erectile dysfunction. ${ }^{154}$ She brought claims under Wisconsin's privacy law, alleging misappropriation of her name to generate financial revenue through online trade and advertising. ${ }^{155}$ The Court of Appeals noted that " $[t]$ he search term

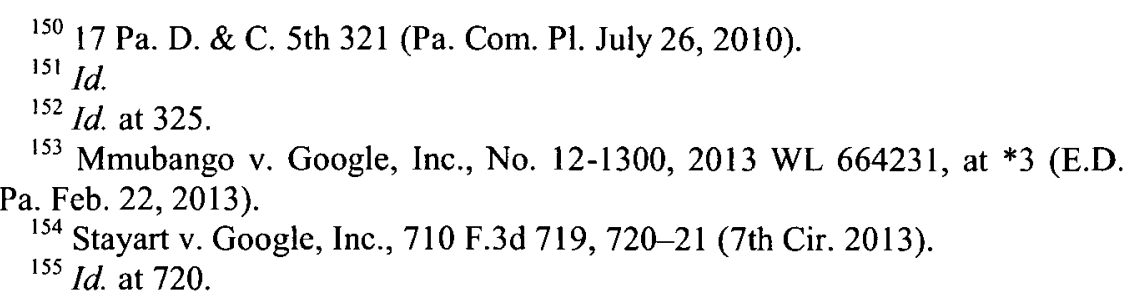


'bev stayart levitra' is a matter of public interest primarily because Stayart has made it one-and, given the current lawsuit, ensures that it remains so." 156 Therefore the court documents from Stayart's lawsuits warrant the public interest exception to Wisconsin's misappropriation law: "It follows that ... the search providers and indexes that lead the public to those documents or that capture key terms related to them are likewise entitled to that exception." 157

Litigants have also been unsuccessful in bringing privacy or intellectual property claims based on Google's advertising programs $^{158}$ or Google Street View. ${ }^{159}$ Functionally, it has been immune from judicial liability. ${ }^{160}$

\section{Internet Search Results Are Already Being Altered}

Aside from the illegality of suits against Google, commentators decry any efforts at regulating the Internet, search engines in particular, as interference with a crucible of free speech. ${ }^{161}$ They believe that any kind of regulation of the Internet violates not only the law but the inherent coda of Internet freedom. ${ }^{162}$ But the fact is

${ }^{156}$ Id. at 723 .

${ }^{157} \mathrm{Id}$.

${ }^{158}$ See Kinderstart.com, LLC v. Google, Inc., No. C 06-2057 JF, 2007 WL $831806,{ }^{*} 1$ (N.D. Cal. Mar. 16, 2007).

${ }^{159}$ See Boring v. Google, 362 Fed. App'x 273, 274 (3d Cir. 2010).

160 Google has, however, been subject to Federal Trade Commission enforcement actions based on its use and sharing of consumers' personal information and its tendency toward monopoly power. See Press Release, Google Will Pay \$22.5 Million to Settle FTC Charges it Misrepresented Privacy Assurances to Users of Apple's Safari Internet Browser, FED. TRADE COMM'N, http://www.ftc.gov/news-events/press-releases/2012/08/google-will-pay-225-

million-settle-ftc-charges-it-misrepresented (last visited Feb. 5, 2014); Sam Gustin, U.S. Google Antitrust Probe Spurs Internet-Regulation Debate, Time (Oct. 15, 2012), http://business.time.com/2012/10/15/ftc-antitrust-probe-againstgoogle-sets-up-internet-regulation-clash/.

${ }_{161}$ See Eugene Volokh, Freedom of Speech and Information Privacy: The Troubling Implications of a Right to Stop People From Speaking About You, 52 STAN. L. REv. 1049 (2000); David Goldstone, The Public Forum Doctrine in the Age of the Information Superhighway, 46 HASTINGS L.J. 335 (1995).

${ }_{162}$ See Preamble, DECLARATION OF INTERNET FREEDOM (2012), available at http://www.internetdeclaration.org/ "We believe that a free and open Internet can bring about a better world. To keep the Internet free and open, we call on 
that speech is already being selected and restricted by search engines themselves. ${ }^{163}$

\section{A. Google's Policy on Removal Requests}

Google provides an online procedure for seeking removal of information from its search results. For example, included in Frequently Asked Questions is "How can I remove information about myself from Google's search results?" Google suggests that removal is only possible by seeking recourse from the website itself:

Google search results are a reflection of the content publicly available on the web. Search engines can't remove content directly from websites, so removing search results from Google wouldn't remove the content from the web. If you want to remove something from the web, you should contact the webmaster of the site the content is posted on and ask him or her to make a change. Once the content has been removed and Google has noted the update, the information will no longer appear in Google's search results. If you have an urgent removal request, you can also visit our help page for more information. ${ }^{164}$

The site also presents the question, "Why do [I] need to contact the webmaster instead of having Google remove the site?" The answer is that the content will still exist on the Internet:

You may dislike a site and want to have it removed from Google search results. However, if we remove this site from Google's search results, the webpage still exists and can be found directly (through the URL to the site) or on other search engines. The fact that it is in Google's index merely reflects that the page exists on the wider web, and not that

communities, industries and countries to recognize these principles."); IFLA Internet Manifesto, IFLA.ORG (2006), available at http://www.ifla.org/publicati ons/the-ifla-internet-manifesto ("Unhindered access to information is essential to freedom, equality, global understanding and peace. . . . The global interconnectedness of the Internet provides a medium through which this right may be enjoyed by all. Consequently, access should neither be subject to any form of ideological, political or religious censorship, nor to economic barriers.").

${ }^{163}$ See Dawn C. Nunziato, The Death of the Public Forum in Cyberspace, 20 BERKELEY TECH. L.J. 1115 (2005).

${ }^{164}$ FAQ-Policies and Principles, GoOGLE, http://www.google.com/policies/ faq/ (last visited Feb. 7, 2014). 
Google endorses it. Instead, your best option is to contact the webmaster who can remove the page entirely. ${ }^{165}$

But in addition to directing users to webmasters, Google appears to offer concrete assistance in some instances. Google's "Webmaster Tools" site contains a page titled "Remove a page or site from Google's search results." 166 If you click the link to "[r]emove content from another site from Google's search results," you are then asked if you want "to [r]emove content for legal reasons," "[r]emove personal information," or "[r]emove content that's not live." 167

If you click to remove content for legal reasons, the site warns that you will be reported to the Chilling Effects Project, ${ }^{168}$ then lists numerous potential legal reasons for your request. ${ }^{169}$ Those issues range from the broad ("I would like incorrect or inaccurate information to be removed from search results" or "I have found a site that is engaging in suspicious behavior") to the highly narrow ("My full name or the name of my business appears on an adult content site that is spamming Google's search results"). ${ }^{170}$

Selecting the first option, "[m]y confidential, personal information is appearing in search results (e.g., security or government ID number, bank account or credit card number, or an image of your handwritten signature)," takes you to the "Removing Information from Google" page and asks whether you have tried contacting the webmaster.

If you indicate that you have done so and they were unresponsive, the site then states, "If the page you're trying to

165 Contact a site's webmaster, GoOGLE, https://support.google.com/ websearch/answer/9109?hl=en (last visited Feb. 7, 2014).

${ }^{166}$ Remove a page or site from Google's search results, GOOGLE, https:// support.google.com/webmasters/answer/164734?hl=en (last visited Feb. 7, 2014).

${ }^{167}$ Remove content from someone else's site, GooGLE, https://support.google. com/webmasters/answer/1663688 (last visited Feb. 7, 2014).

${ }^{168}$ The Chilling Effects Project is a joint project among U.S. law schools that monitors requests to remove information from the Internet. See Removing Content from Google, GOOGLE, https://support.google.com/legal/troubleshooter/ 1114905 ? $\mathrm{rd}=1 \#$ ts=1115655; see also CHILLING EFFECTS, http://www.chilling effects.org (last visited Feb. 7, 2014).

${ }^{169}$ Removing Content from Google, supra note 168.

${ }^{170} \mathrm{Id}$. 
remove from Google's search results displays sensitive personal information, we may be able to help." 171 While Google states that "there is very little that we remove from search results on a discretionary basis," it does claim to take action on certain types of sensitive information and spam. Google states that it will remove personal information upon request if that information "could make a user susceptible to specific harm, such as identity theft or financial fraud." 172 Such personal information can include social security numbers, bank and credit card account numbers, and images of signatures. ${ }^{173}$ Google will not remove generic personal information like date of birth, address, or telephone numbers. ${ }^{174}$ In determining whether a particular form of identification is considered sensitive, Google focuses on whether it is a government-issued identification number, confidential or publicly available, or capable of being used for common commercial transactions. ${ }^{175}$

If the user proceeds to attempt to remove personal information, the site then asks the user if the information at issue is one of the following:

Contact information, such as phone number, email address or username; [a] picture of myself; [a] government-issued ID number; [a]n image of my handwritten signature; [a] pornographic site that contains a full name or business name; [i]ncorrect or inaccurate information about myself; [a]n inappropriate, malicious or spammy site; [or o]ther content which should be removed based on applicable laws. ${ }^{176}$

If the user selects the first choice, confidential information such as phone number, email address, or username, Google again refers the user to the webmaster, stating:

\footnotetext{
${ }^{171} I d$.

${ }^{172}$ Removal Policies, GoOGLE, https://support.google.com/websearch/answer/ 2744324 (last visited Feb. 7, 2014).

${ }^{173} \mathrm{Id}$.

${ }^{174} \mathrm{Id}$.

${ }^{175} I d$.

${ }^{176}$ Remove information from Google, GoOGLE, https://support.google.com/ websearch/troubleshooter/3111061?hl=en (last visited Feb. 10, 2014).
} 
If you've found something on the Web that you'd like to have removed, you need to contact whoever controls that content. Most often, this means that you need to contact the webmaster of the page and ask them to take down the content in question. Even if you found the objectionable content using Google, Google doesn't have control over the sites we list in our search results. ${ }^{177}$

If the information is instead a government issued ID, bank account or credit card information, or a copy of a signature, Google provides a mechanism for reporting the website that contains the information. ${ }^{178}$ Google checks that the user has contacted the website itself, which "ensures the most complete removal of [the] information," and not had success. ${ }^{179}$ If that is the case, the user is directed to complete a form so that Google can investigate. ${ }^{180}$

If you indicate that the information you are trying to remove is defamatory, the site allows you to choose the "[r]eport other legal removal issue" option. ${ }^{181}$ The online form asks for the complainant's name, contact information, infringing URL and search query used, and requests that the complainant check a box swearing under penalty of perjury that the information is accurate. ${ }^{182}$

Google also allows users to report malicious software, submit a spam report, report fraudulent sites in ads, and request removal of personal information from pornographic sites. ${ }^{183}$

Thus, although Google repeatedly informs its users that it only rarely removes third party content and that the user should contact that website directly, it does provide avenues for reporting of sensitive information, defamatory material, and other harmful content. Of course, Google gives little information about the requests it receives or how it responds to them.

\footnotetext{
${ }^{177}$ See Contact a site's webmaster, supra note 165.

${ }^{178}$ See Remove information from Google, supra note 176.

${ }^{179} \mathrm{Id}$.

${ }^{180} \mathrm{Id}$.

${ }^{181}$ Report other legal removal issue, GOOGLE, https://support.google.com/ legal/ contact/lr_legalother?product=websearch (last visited Feb. 7, 2014).

${ }^{182} \mathrm{Id}$.

${ }^{183}$ See Remove information from Google, supra note 176.
} 


\section{B. Google's Actions in Response to Removal Requests}

The ultimate decision to make available an avenue for the removal of controversial material from search engines was apparently made by a single Google lawyer. Professor Jeffrey Rosen described Google's decision-maker as "the person who arguably had more power than any other to determine who may speak and who may be heard around the globe." 184 Now Rosen reports that there are multiple "Deciders," young people in charge of the site's content policy: "Their positions give these young people more power over who gets heard around the globe than any politician or bureaucrat - more power, in fact, than any president or judge." $" 185$ But the decisions of these powerful people are far from transparent.

In apparent recognition of the value of informing the public of at least some of the removal requests it receives, Google began releasing a "Transparency Report" in 2010 to "shine some light on the scale and scope of government requests for censorship and data around the globe." 186 Unfortunately, the report only provides information about requests Google receives from copyright owners and from governments. ${ }^{187}$ And the report provides little information

184 Jeffrey Rosen, The Deciders: Facebook, Google, and the Future of Privacy and Free Speech, BROOKINGS INSTITUTION (May 2, 2011), available at http:// www.brookings.edu/research/papers/2011/05/02-free-speech-rosen.

${ }^{185}$ Jeffrey Rosen, The Delete Squad: Google, Twitter, Facebook and the new global battle over the future of free speech, THE NEW REPUBLIC (Apr. 29, 2013), available at http://www.newrepublic.com/article/113045/free-speech-internetsilicon-valley-making-rules.

${ }^{186}$ Transparency Report: More government removal requests than ever before, GOOGLE, http:/www.googleblog.blogspot.com/2013/04/transparency-report-moregovernment.html (last visited Jan. 17, 2014).

${ }^{187}$ Professors Derek and Jane Bambauer obtained further clarification about Google's process:

In discussions with the Google Transparency Report team, we learned about the firm's process for classifying requests. Employees working on various Google products (such as YouTube) distributed around the world receive government requests to take down content. They report each request using a standardized form. The employee reporting the request is responsible for classifying it, based principally on the legal basis cited by the government for the request. However, Google classifies requests as related to government criticism based upon its 
about how Google responds to specific requests. But Google does indicate that it removes some material in response to individual requests:

The statistics we report here do not include content removals that we regularly process everyday in response to non-governmental user complaints across our products for violation of our content policies or community guidelines ... [which in many cases] result in the removal of material that violates local law, independent of any government request or court order seeking such removal. ${ }^{188}$

Google does not provide information about the number or type of such requests, or the reasons for its response. ${ }^{189}$

Content removal requests containing court orders are included in the transparency report. For example, in the latter part of 2012, Google "received three court orders from different individuals that were addressed to third parties, along with requests to remove 452 search results that linked to websites that allegedly contain defamatory content." ${ }^{\prime 190}$ Google noted that of those 452 it removed, "70 search results that [Google] determined to fall within the scope of the orders." orders, but relies on its own discretion to determine the scope and application of those orders. Similarly, in the latter part of 2011 it received "a court order to remove 218 search results that linked to allegedly defamatory websites," but removed only twenty-five

own, internal criteria. Google's transparency team and legal department review almost every such request, and may re-classify them for consistency or quality control. And, there are instances where the request comes with no reason or legal basis cited; Google classifies such requests as Removal Reason Not Specified. Finally, Google divides request mechanism into two categories: court order (including instances where a requester attaches a relevant court order, but Google is not a party), and other.

Bambauer \& Bambauer, supra note 113, at 148.

${ }^{188}$ Transparency Report FAQ, GOOGLE, http://www.google.com/transparency report/removals/government/faq/ (last visited Jan. 17, 2014).

${ }^{189}$ See id.

190 Transparency Report United States, GOOGLE, http://www.google.com/ transparencyreport/removals/government/US/?by=product\&p=2012-12 (last visited Jan. 17, 2014).

${ }^{191} I d$. 
percent of the results cited in the request. ${ }^{192}$ Google's rate of compliance with U.S. requests has declined from eighty-three percent in the last six months of 2010 to forty-eight percent in the last six months of $2012 .{ }^{193}$

Google describes some specific requests related to YouTube and Google Groups. In the second half of 2012, it received "a request from a local government agency to remove a YouTube video that allegedly defamed a school administrator," and "three separate requests from local law enforcement agencies" to remove YouTube videos "that allegedly defamed police officers, public prosecutors or contained information about police investigations," but did not remove any of the requested videos. ${ }^{194}$ Google "removed 771 items from Google Groups relating to a case of continuous defamation against a man and his family."195

Rosen describes an instance in which Google agreed to remove "jihadist videos" upon demand by a U.S. Senator. ${ }^{196}$ In another instance, when users manipulated search rankings so that the query 'Jew' returned a Holocaust-denial site in its top ten results, Google responded to complaints by adding a headline explaining the results. ${ }^{197}$ As Pasquale notes, "[w] hen confronted by important enough entities, Google does intervene in search results." 198

In addition to the evidence of Google's actions in response to removal requests, there is evidence of individuals allegedly harmed by Google's exclusion as opposed to inclusion choices. ${ }^{199}$ Many have accused Google of hand-editing its own search results in order to punish behavior it views as violating its Terms of Service.

192 Tranparency Report: Requests to remove content, GoOGLE, http://www. google.com/transparencyreport/removals/government/US/?p=2011-12 (last visited Feb. 5, 2014).

${ }^{193}$ Bambauer \& Bambauer, supra note 113, at 144.

${ }^{194}$ Transparency Report United States, supra note 190.

${ }^{195} \mathrm{Id}$.

${ }^{196}$ Rosen, The Deciders, supra note 184.

${ }^{197}$ Pasquale, Rankings, supra note 39, at 121-22.

${ }^{198}$ Id.

199 See Pasquale, Beyond Innovation, supra note 28, at 110 (describing the forms of bias introduced by a search engine in removing websites from its index or reducing their rankings). 
The owner of 2bigfeet.com, a seller of large-sized men's shoes, says that in November 2003, his site disappeared from the first page of Google's results for terms like "big shoes" when Google suddenly changed its algorithm. ${ }^{200}$ The site owner tried repeatedly to contact Google but did not get a response. Google later "claimed that [the site owner] may have hired a search engine optimizer who ran afoul of its rules but it would not say precisely what those rules were."201

Web business owner Dan Savage, who had benefitted from Google referrals to his page, Sourcetool, discovered in the summer of 2006 that his site had disappeared from Google search results. ${ }^{202}$ When asked, Google executives reported that Sourcetool's "landing page quality" was low and did not meet the standards of Google's recently changed algorithm for choosing advertisements for prominent positions on Google search pages. ${ }^{203}$ Although the company never told Mr. Savage what, precisely, was wrong with his landing page quality, it offered some suggestions for improvement, none of which actually improved his results. ${ }^{204}$ Similarly, the plaintiff in Langdon alleged that Google removed his website from its search results for "Roy Cooper" and "Attorney General Roy Cooper," and that during the time in question the same search on MSN ranked his website at eight. ${ }^{205}$ The plaintiff claimed that Google fraudulently implied it was legally compelled to remove his website from its search results, but that Google

${ }^{200}$ BATTELLE, supra note 120 , at 156.

${ }^{201}$ Pasquale, Restoring Transparency, supra note 37, at 246.

202 Joe Nocera, Stuck in Google's Doghouse, N.Y. TIMES (Sept. 12, 2008), http://www.nytimes.com/2008/09/13/technology/13nocera.html.

${ }^{203} \mathrm{Id}$.

${ }^{204}$ Google executives suggested "running fewer AdSense ads and manually typing in the addresses and phone numbers of the 600,000 companies in his directory. . . . At a cost of several hundred thousand dollars, he made some of the changes Google suggested . . . [with] [n]o improvement." Id.

${ }^{205}$ Langdon v. Google, Inc., 474 F. Supp. 2d 622 (D. Del. 2007) (dismissing claims by website owner against defendants for their alleged refusal to run his website ads). 
reinstated the website after he filed his complaint, "prov[ing] that the initial delisting was fraudulent, arbitrary, and punitive."206

The head of the webspam team at Google ${ }^{207}$ confirmed that Google penalizes sites that use search engine optimization ("SEO") in violation of its guidelines. ${ }^{208}$ But SEO is still a booming industry. ${ }^{209}$ Not surprisingly, a cottage industry of non-legal measures has arisen both to help prevent the bad information from being posted to begin with ${ }^{210}$ and to counteract bad information that leads search results. ${ }^{211}$ The companies that offer to repair reputation and hide personal information do so by flooding the Internet with positive information that buries the negative below it. Despite Google's efforts to fight it, the "relevance" of search results is already being gamed based on a person's ability to pay for the service rather than any valid argument for removal of the

${ }^{206}$ Id. at 627; see also Search King v. Google, No. CIV-02-1457-M, 2003 WL 21464568 (W.D. Okla. May 27, 2003); Kinderstart.com LLC v. Google, Inc., No. C 06-2057 JF, 2006 WL 3246596 (N.D. Cal. Mar. 17, 2006) (regarding allegations of "blockage"); Grimmelmann, supra note 49 (manuscript at 28) (describing the allegations of Adam Raff that Google demoted his company Foundem, which "effectively 'disappeared' from the Internet").

${ }^{207}$ This is how Matt Cutts describes himself on his Twitter account. See Matt Cutts' Profile, TwITTER, https://twitter.com/mattcutts/status/38690934619963 8016 (last visited Jan. 16, 2014).

${ }^{208}$ Lastowka, supra note 45, at 1354 n.126 (quoting Matt Cutts' blog posting about removing traffic-power.com from its index).

${ }^{209}$ See Ambrose, You Are What Google Says You Are, supra note 64, at 24-25 (describing the market for improving an individual's search results); Lastowka, supra note 45 , at 1346 ("[T] he SEO economy is here to stay and is currently valued at $\$ 4.1$ billion.").

210 This includes "Tiger Text"-disappearing text with time limits of one minute to thirty days. See Jef Ausloos, The "Right to be Forgotten" - Worth Remembering?, 28 COMPUTER L. \& SECURITY REV. 143, 153-54 (2012). There is a new app called FaceWash which "scans your posts, timeline, and tagged photos to make sure nothing incriminating is going on, and warns you if it finds anything." Alan Henry, FaceWash Makes Sure Your Facebook Profile Is Clean and Interview-Ready, LIFEHACKER (Jan. 28, 2013), http://lifehacker.com/59788 72/facewash-makes-sure-your-facebook-profile-is-clean-and-interview+ready.

${ }^{211}$ Companies like Reputation Defender and ReviewBoost promise to improve online image for a fee. See REPUTATION.COM, http://www.reputation.com/ (last visited Feb. 10, 2014); REVIEW BoosT, http://reviewboost.com/?gclid= CKjypLi UvbwCFQjxOgodhEQAaw (last visited Feb. 10, 2014). 
information. ${ }^{212}$ Despite Google's efforts to prevent "gaming" of the system, its search results are manipulated by companies like "Reputation Defender" and "Reputation.com." 113

\section{Tweaking the Algorithm}

Finally, Google has been receptive to calls for altering its algorithm based on what it views as harmful website behavior. According to Google's webspam head, an article criticizing mugshot "extortion" sites was "the major spark" behind Google's recent decision to tweak its algorithm and downgrade the Page Rank of mugshot websites. ${ }^{214}$

In October 2013, an article in the New York Times described the phenomenon of mugshot websites, which publicize arrest photos on their sites and then offer to remove those photographs for a fee. ${ }^{215}$ The article described how those mugshots remain online even though the arrestee may have been innocent or otherwise has moved on from the incident. ${ }^{216}$ The article also stated that the sites' popularity in response to Google searches poses problems for the arrestees and further incentivizes the extortion plot. $^{217}$ At first, a Google spokesman responded that the company

${ }^{212}$ See Ambrose, You Are What Google Says You Are, supra note 64, at 24 ("This form of intervention may promote the goals of reputation rehabilitation, but it is not information stewardship. . . . [T] hese services 'edit' the Internet, creating search barriers to valuable, as well as valueless, information.").

213 See id. at 24-25 (describing the market for improving an individual's search results); Lastowka, supra note 45, at 1352-54 (describing search engine optimization and Google's retaliatory techniques).

${ }^{214}$ Barry Schwartz, Google Launches Fix To Stop Mugshot Sites From Ranking: Google's Mugshot Algorithim, SEARCH EnGINE LAND (Oct. 7, 2013, 9:36 AM), http://searchengineland.com/google-launches-fix-to-stop-mugshot-sit es-from-ranking-googles-mugshot-algorithm-173672.

${ }^{215}$ See David Segal, Mugged by a Mugshot Online, N.Y. Times (Oct. 5, 2013), http://www.nytimes.com/2013/10/06/business/mugged-by-a-mug-shotonline.html?pagewanted=all\&_r=1\&.

${ }^{216} \mathrm{Id}$.

${ }^{217}$ Id. ("In the eyes of anyone who searches for Mr. Birnbaum online, the taint could last a very long time. That's because the mugshot from his arrest is posted on a handful of for-profit Websites, with names like Mugshots, Busted Mugshots and Just Mugshots. These companies routinely show up high in Google searches; a week ago, the top four results for 'Maxwell Birnbaum' were mug-shot sites.”). 
sympathized with those affected by mugshot sites but that "with very narrow exceptions, we take down as little as possible from search." ${ }^{218}$ Two days later, he wrote with an update: "Our team has been working for the past few months on an improvement to our algorithms to address this overall issue in a consistent way. We hope to have it out in the coming weeks." 219 When the algorithm change went into effect, mugshots that had formerly appeared prominently in an image search were no longer on the first page. ${ }^{220}$

One media outlet applauded Google's decision to downgrade the mugshot websites in its search results, stating, "This change should help many innocent people sleep better at night, knowing their work, colleagues, family and children are less likely to see past arrest charges that they may or may not have been found guilty for. ${ }^{\text {"22I }}$ Others point out potential negative implications:

Obviously, Google tweaks its algorithms all the time to boost or lower the ranking of different types of content. And both it and MasterCard are private corporations that can do whatever they wish-within reason--when it comes to their business. We may even agree that mugshot sites are reprehensible and deserve to die. But what happens when Google and/or MasterCard decide to target other sites? What if they choose to cut off WikiLeaks, for example, as MasterCard did in $2010 ?^{222}$

The New York Times pointed out the outsized power that Google has: "If it acted, Google could do what no legislator could -demote mug-shot sites and thus reduce, if not eliminate, their power to stigmatize." 223 With one tweak to its algorithm, that is exactly what Google did.

\section{The Proposal: Guiding Google's Choices}

Google should lead the way in recognizing that, like the mugshots websites, certain harmful information online should not

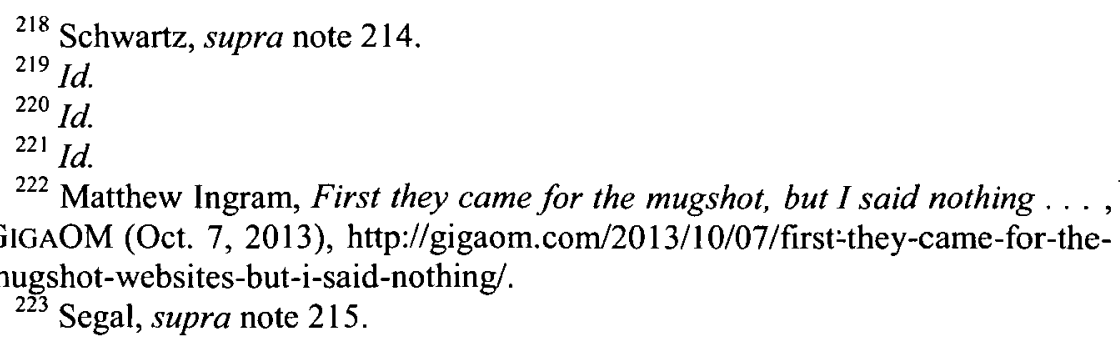


top generic search results, such as for a person's proper name. ${ }^{224}$ This Article proposes that Google continue to follow its own procedure with respect to seeking information about removal requests, but that it offer redress when the user has tried and failed to get recourse from the website itself. This is a less severe proposal than that of deletion or erasure, but it addresses the primary issue many people have with certain information being among the most visible results of a Google search of their name or business. ${ }^{225}$ Under the proposal, the standard is lower than requiring production of a court order of deletion. The requester must satisfy the reviewer that the information falls within a protected category. Google should further require that before it take any action, the user has exhausted her remedies by seeking removal of the information from the website itself. This approach would not require that a lawsuit be brought. ${ }^{226}$

\section{A. Categories of Online Suppression}

Because search results are altered or hand-edited, and Google's algorithm is tweaked on occasion, Google should clarify the types of information properly subject to some kind of suppression.

\section{The Information is Confidential and Personal}

Google asks users seeking removal if their request falls within the "confidential and personal" category, and Google distinguishes this type of removal request from more general misleading

${ }^{224}$ Frank Pasquale has recognized the importance of search of individuals' proper names and has recommended that individuals be able to annotate harmful information that appears in response to such searches. This would give them the right "not to suppress the results, but merely to add an asterisk to the hyperlink directing web users to them, which would lead to the complainant's own comment on the objectionable result." Pasquale, Rankings, supra note 39, at 122.

${ }^{225}$ Research shows most Internet search engine users do not advance past the first screen of results. So one requested result might be to suppress information such that it does not appear on that first screen. See Chandler, supra note 72, at 1107-08 (noting the phenomenon of "screen bias," the preference for results listed in the first screen of search results).

${ }^{226}$ If an individual has brought suit and has a court order finding information to be defamatory or ordering a defendant to stop harassing the plaintiff, the order itself is prima facie evidence in favor of the removal request. 
information. With respect to some types of confidential and personal information, Google allows the user to submit a request for removal. But if the information is not one of those specified (government-issued ID, credit card number, bank account number, or image of a handwritten signature), Google gives the user the same response as to any non-confidential material-seek removal from the website itself. ${ }^{227}$ Google is in a position to help tremendously with problems like identity theft by removing or demoting webpages that contain sensitive personal information when those sites have refused to remove the content.

State and federal laws protect against the disclosure of sensitive medical, financial, and other personal information. ${ }^{228}$ Indiana has one such law, which gives taxpayers a right to delete information from department of taxation letters of findings, including name and address information, trade secrets and other commercial or financial information, and any other information "the disclosure of which would constitute an unwarranted invasion of personal privacy." 229 Similarly, the Freedom of Information Act's ("FOIA") Exemption 6 protects information about individuals in "personnel and medical files and similar files" when the disclosure of such information "would constitute a clearly unwarranted invasion of personal privacy[.]"230 These types of highly personal information may be worthy of removal,

\footnotetext{
${ }^{227}$ See supra Part IV.A.

${ }^{228}$ See, e.g., Health Insurance Portability and Accountability Act of 1996, 45
} C.F.R. $\S 162$ (2014) (setting forth numerous requirements of confidentiality in the use and transmission of health information); Gramm-Leach-Bliley Act, 15 U.S.C. $\$ 6821$ (2012) (requiring that financial institutions protect the privacy of their customers' personal information); N.Y. GEN. BUS. LAW $\S 380-q$ (McKinney) (limiting disclosure of medical information to a physician designated by the consumer for such purpose); CAL. FIN. CODE $\S 4052.5$ (West) (prohibiting financial institutions from disclosing consumers' nonpublic personal information without explicit prior consent); $\mathrm{MICH}$. COMP. LAWS ANN. $\S 445.83(2)$ (a) (prohibiting individuals or entities from publicly displaying an individual's Social Security number under certain circumstances); N.Y. EDUC. LAW $\S 2-b$ (prohibiting the use of student Social Security numbers for identification purposes).

${ }^{229}$ IND. CODE ANN. $§ 6-8.1-3-3.5$ (West 2012).

${ }^{230} 5$ U.S.C. $\S 552(\mathrm{~b})(6)(2012)$. 
particularly where the party responsible for its publication is difficult to locate.

\section{The Information Relates to a Minor}

Google's help pages allow a person seeking to remove content to specify that the content is "abusive of minors." "231 But if you select that option, the only assistance Google offers is a link to the National Center for Missing and Exploited Children, or to general information about "how to keep your family safe while browsing the Web." ${ }^{232}$ Google offers to help remove a user's bank account information from its results but only offers platitudes if those results include content that is abusive of minors. Instead, Google should, at minimum, allow a user to report the harmful information and consider taking action itself.

The online privacy of minors is of critical importance to most Americans. One example is a recently passed California bill that would prohibit websites and applications from marketing or advertising specific types of products or services to a minor, or from compiling, using or disclosing personal information of a minor. ${ }^{233}$ The bill, called "Privacy Rights for California Minors in the Digital World," also would require a website or online service to permit a minor "to request and obtain removal of, content or personal information posted on the operator's Internet Web site, online service, online application, or mobile application by the user." ${ }^{234}$ Legislators have proposed amendments to the Children's Online Privacy Protection Act that "would create an 'Eraser Button' so parents and children could eliminate publicly available personal information content, when technologically feasible."235

${ }^{231}$ Report content that is abusive of minors, GoOGLE, https://support.google. $\mathrm{com} /$ websearch/answer/148666?hl=en (last visited Jan. 16, 2014).

${ }^{232}$ These are the options if the user wishes to report abuse in the United States. See id. Google also provides information for reporting abuse to government hotlines of other countries. See id.

${ }^{233}$ See S. 568, 2013-2014 Leg., Reg. Sess. (Ca. 2013).

${ }^{234} I d$. The bill would not require removal of content posted by a third party. Id.

${ }^{235}$ Press Release, Mark Kirk U.S. Senator for Illinois, Kirk, Markey, Barton, Rush Introduce 'Do Not Track Kids' Act (Nov. 14, 2013), available at http:// www.kirk.senate.gov/?p=press_release\&id=932. Other precedents for Google's 
Google's chief executive is even on record supporting the rights of minors to delete information about themselves online:

[The] Internet needs a delete button, Google Executive Chairman Eric Schmidt said Monday. Actions someone takes when young can haunt the person forever, Schmidt said, because the information will always be on the Internet. He used the example of a young person who committed a crime that could be expunged from his record when he's an adult. But information about that crime could remain online, preventing the person from finding a job. "In America, there's a sense of fairness that's culturally true for all of us," Schmidt said. "The lack of a delete button on the Internet is a significant issue. There is a time when erasure is a right thing., 236

Google's actions should match its words in the context of minors.

\section{The Information is Untrue or Defamatory, or No Longer "Relevant"}

The defamatory or outdated information category is likely the most controversial because it most clearly pits free speech against suppression of information, including opinion. But there are cogent reasons why Google should factor in the information's inaccuracy, defamatory nature, prejudicial value, or age in determining the relevance of that information in its search results.

Google is not legally required to take down defamatory material, as it notifies its users, although it claims to do so upon court order. ${ }^{237}$ But requiring a victim of defamation to bring suit

protection of information about minors include juvenile criminal law which provides for sealing or expungement of juvenile criminal records. See, e.g., ALA. CODE $\S 12-15-136 ; 705$ ILL. STAT. 405/5-915; KY. STAT. $\S 610.330$; MAsS. STAT. $276 \S 100 B$; N.J. STAT. § 2C:52-4.1(b); S.C. CODE ANN. § 63-19-2050.

${ }^{236}$ Shara Thibken, Google's Schmidt: The Internet Needs a Delete Button, CNET (May 6, 2013), http://news.cnet.com/8301-1023_3-57583022-93/googlesschmidt-the-internet-needs-a-delete-button/?part=rss. Google also emphasizes its opposition to and efforts to fight child pornography. Eric Schmidt, 'We've Listened-and Here's How We'll Halt This Depravity': Google Chief Eric Schmidt Explains Block on Child Porn, DaILY MAIL (Nov. 17, 2013), http:// www.dailymail.co.uk/news/article-2509044/Google-chief-Eric-Schmidtexplains-block-child-porn.html.

${ }^{237}$ Google makes its own determination as to the scope of court orders. See supra Part IV.B. Google notified a libel victim seeking to report a non-intellectual property issue as follows: 
and present Google with a court order is problematic for many reasons. First, a lawsuit only draws more attention to the negative comments. Recently, a California neurosurgeon sued a former patient whose wife died of complications from bone cancer after the doctor cared for her. ${ }^{238}$ The patient blogged about the experience, indicating that the doctor had caused deaths, and the doctor sued for defamation, saying the blog damaged his career. ${ }^{239}$ Ironically, the lawsuit itself has resulted in more media attention than the original blog, highlighting the catch-22 for anyone harmed by online defamation: "Trying to have content removed from Google's index by way of a lawsuit generates news coverage of said lawsuit and perpetuates the information the person is trying to suppress. $" 240$

Second, even if a victim has incurred the time and expense of seeking a court order, that order is sometimes ineffective. Google admits that it makes its own determination as to what falls within

Google.com is a US site regulated by US law. Google provides access to publicly available webpages, but does not control the content of any of the billions of pages currently in the index. Given this fact, and pursuant to section 230(c) of the Communications Decency Act, Google does not remove allegedly defamatory material from our search results. You will need to work directly with the webmaster of the page in question to have this information removed or changed.

Search Results: Despair-Google ${ }^{\circledR}$ Denies Relief to Victims of Libel, REXXFIELD (2008), http://www.rexxfield.com/GoogleAllowsLibel.html.

${ }^{238}$ Liz Kowalczyk, Fight Over Patient's Online Critique Continues in Court, THE BoSTON GLOBE (Sept. 25, 2013), http://www.bostonglobe.com/lifestyle/ health-wellness/2013/09/25/doctors-sue-and-patient-online-critiques-comedown-but-fight-over-damages-continues-court/A5gMXULNOVVm9bU2 YTYDOL/story.html.

${ }^{239}$ Id. "Her lawsuit is part of a wave of claims brought by doctors against former patients, and sometimes their relatives, over negative ratings and reviews they have posted on the Internet. These reviews have shifted the balance of power among doctors and patients. And while some lawyers say doctors only draw more attention to negative comments by suing over them, Filler said sometimes a physician needs to take strong action." Id.

240 Miranda Miller, Miami Heat Minority Owner Sues Google Over Unflattering Photo, SEARCH ENGINE WATCH (June 26, 2012), http://search enginewatch.com/article/2187277/Miami-Heat-Minority-Owner-Sues-GoogleOver-Unflattering-Photo. 
the scope of a court order. ${ }^{241}$ Furthermore, obtaining a court order in one country may be ineffective in another. ${ }^{242}$

With respect to outdated information, there is well-documented precedent for suppressing information that would inhibit individuals' rehabilitation. While the Supreme Court has rejected claims for liability based on publication of information about the past crimes of rehabilitated individuals, ${ }^{243}$ there is still substantial historical precedent in the United States for supporting individuals' ability to reform themselves and free themselves from reminders of

${ }^{241}$ Transparency Report, supra note 112.

${ }^{242}$ See infra Part V.A.4 (discussing Lee David Clayworth's ineffective Malaysian court order).

${ }^{243}$ Two early California cases upheld liability for invasion of privacy based on publication of information about criminal activity in a "former life." In Briscoe v. Reader's Digest Ass' $n, 483$ P.2d 34 (Cal. 1971), the plaintiff stated a cause of action for invasion of privacy where the defendant published plaintiff's name in connection with criminal activity eleven years before. The court stated that a jury could reasonably find that plaintiff's identity as criminal was not newsworthy, given its minimal social value, gross offensiveness, lack of voluntary consent, and effect on rehabilitation: "Once legal proceedings have terminated, and a suspect or offender has been released, identification of the individual will not usually aid the administration of justice. Identification will no longer serve to bring forth witnesses or obtain succor for victims. Unless the individual has reattracted the public eye to himself in some independent fashion, the only public 'interest' that would usually be served is that of curiosity." Id. at 40. Similarly, in Melvin v. Reid, 297 P. 91, 93 (Cal. Ct. App. 1931), the court upheld liability based on "[t]he use of appellant's true name in connection with the incidents of her former life," which the court found to be "unnecessary and indelicate, and a willful and wanton disregard of that charity which should actuate us in our social intercourse, and which should keep us from unnecessarily holding another up to the scorn and contempt of upright members of society." Compare Briscoe, 483 P.2d 34, and Melvin, 297 P. 91, with Sipple v. Chronicle Publ'g Co., 154 Cal. App. 3d 1040 (1984) (although the publication of facts about Sipple was not long after the incident in which he saved the president's life); Haynes v. Alfred A. Knopf, Inc., 8 F.3d 1222 (7th Cir. 1993) (finding newsworthy revelations about intimate and embarrassing details about plaintiffs' past lives because of their context in a study on migration of blacks to the North). But the California Supreme Court overturned Briscoe in Gates v. Discovery Commc'ns Inc., 101 P.3d 552, 559 (Cal. 2004), acknowledging that Supreme Court precedents compelled it to do so. See Gates, 101 P.3d at 687 (citing Cox Broadcasting v. Cohn, 420 U.S. 469 (1975)). 
their pasts. ${ }^{244}$ Indeed, Google's recent "tweak" of its algorithm to remove mugshot websites from search results shows an awareness of the prejudicial effect of such information regardless of its truthfulness. ${ }^{245}$

In addition, state expungement statutes show a public policy favoring downgrading information about a person's past. Connecticut, for example, has an "erasure statute" that provides for the sealing, erasure and, in certain cases, destruction of police, court, and prosecutorial records pertaining to criminal charges that do not result in conviction or for which the defendant has been pardoned. ${ }^{246}$ The law even forbids the Clerk of Court, or "any person charged with the retention and control of erased records," from disclosing their existence or information contained therein. ${ }^{247}$ Other examples of legal recognition of the value of downgrading older information include bankruptcy law and credit reporting laws such as the Fair Credit Reporting Act, which prohibits creditreporting agencies from retaining information for more than ten years. ${ }^{248}$

4. The Information is Otherwise Unduly Harmful, such as that Likely to Result in Bullying or Stalking

Google again has no legal duty to assist in situations where a person is being stalked or harassed online. ${ }^{249}$ But it could use its considerable power to lessen the effects of those actions by minimizing the prominence of such harmful activities on Google search results. Even more than in the defamation context, legal avenues have proved ineffective in fighting online stalking or harassment.

\footnotetext{
${ }^{244}$ See generally Ambrose, Seeking Digital Redemption, supra note 64.

${ }^{245}$ See supra Part IV.C.

${ }^{246}$ CONN. GEN. STAT. ANN. § 54-142a (West 2012); see Connecticut v. West, 472 A.2d 775 (Conn. 1984).

${ }^{247}$ CONN. GEN. STAT. ANN. $§ 54-142 \mathrm{c}(\mathrm{a})$; see Cloukey v. Leuba, 788 A.2d 1275 (Conn. Super. Ct. 2000) (concerning applicability of revised statute which excludes trial transcripts from records requiring erasure).

${ }^{248}$ See Ambrose, Seeking Digital Redemption, supra note 64, at 154-55 (discussing FCRA, bankruptcy systems).

${ }^{249}$ See supra Part III.
} 
Clayworth, the Canadian whose job prospects were negatively impacted by his ex-girlfriend's digital harassment, obtained court orders against her in Malaysia, including for contempt of court; nevertheless, the harassment has continued. ${ }^{250}$ The court that issued the orders against Clayworth's ex-girlfriend also ordered search engine providers Google, Yahoo and Bing to block Clayworth's name from being searchable; those orders too have proven to be unenforceable. ${ }^{251}$ Clayworth has sent the court order to all three companies but has had no positive response. ${ }^{252}$ In response to a reporter's questions about Clayworth's case, Google's spokesperson reiterated that users who want content removed should contact the webmaster directly, and that Google does not remove content from its search results "except in very limited cases such as illegal content and violations of [their] webmaster guidelines." ${ }^{253}$ When told that the postings about Clayworth were deemed illegal by a Malaysian court, the spokesperson suggested that that made no difference: Google responded, "[Again], even if we did remove the name it would not make the content disappear from other places on the web, since Google's search results are a reflection of the content and information that is available on the web." 254

Google could assist victims like Clayworth by suppressing the harmful information or preventing a search of his name. Google could protect victims like Erin Andrews by suppressing the videotape illegally filmed by her stalker, rather than allowing it to appear at the top of Google searches for her name. ${ }^{255}$ Finally, it could help teenage girls like Amanda Todd by allowing her to suppress the photograph that elicited harmful comments and cyberbullying, ultimately leading to her suicide. ${ }^{256}$

\footnotetext{
${ }^{250}$ Tomlinson, supra note 78.

${ }^{251} I d$.

${ }^{252} I d$.

${ }^{253} \mathrm{Id}$.

${ }^{254} \mathrm{Id}$.

${ }^{255}$ See Pesta, supra note 123.

${ }^{256}$ Lateef Mungin, Bullied Canadian Teen Leaves Behind Chilling YouTube Video, CNN (Oct. 12, 2012), http://www.cnn.com/2012/10/12/world/americas/ canada-teen-bullying/index.html?hpt=hp_c2; see also Ambrose, Seeking Digital Redemption, supra note 64, at 116-17.
} 


\section{B. In Google's Best Interests}

Commentators have noted that Internet companies like Google and Facebook "face a public that increasingly is more inclined to blame them for cyber-bullying and other online transgressions."257 The highly publicized incident of cyber-bullying resulting in the suicide of teen Megan Meier may have been responsible for MySpace's downturn in popularity: "We are a society that expects companies and people of authority to take responsibility, not only for their own actions but for the actions of those beneath them," says an expert on online communities. ${ }^{258}$ In another case, Google was recently ordered to turn over identity and contact information for an online bully, even though the comments and video have since been removed, a step the victim says shows that "the Internet cannot become a haven for harassers and criminals." 259

Online privacy is gaining increasing attention from Congress and the White House, as well as from states like California. The White House's "Consumer Privacy Bill of Rights" states in its opening letter that "[n] ever has privacy been more important than today, in the age of the Internet, the World Wide Web and smart phones." ${ }^{260}$ One of those rights outlined in the report relates to "Access and Accuracy," stating that "[c]onsumers have a right to access and correct personal data in usable formats, in a manner that

${ }^{257}$ Dan Whitcomb, Cyber-Bullying Cases Put Heat on Google, Facebook, REUTERS (Mar. 9, 2010), http://www.reuters.com/article/2010/03/09/us-internetbullying-idUSTRE6275UG20100309 ("The Internet was built on freedom of expression. Society wants someone held accountable when that freedom is abused. And major Internet companies like Google and Facebook are finding themselves caught between those ideals."). The article also discusses the Italian court conviction of Google executives for failing to take down a bullying video posted on YouTube, a decision later overturned. Id.

${ }^{258}$ Id. (quoting Karen North, director of the Annenberg Program on Online Communities at the University of Southern California). She further states, "The difficulty is, we've created an Internet culture where people are invited to put up content, but the responsibility falls in both directions.... (On the Internet) we all share the responsibility to monitor the content that we find and for our societal standards to be maintained." Id.

${ }^{259} \mathrm{Ki}$ Mae Heussner, Google Ordered to Name Anonymous Online Bullies, ABC NEWS (Oct. 22, 2010), http://abcnews.go.com/Technology/google-orderedonline-bullies-anonymously-bullied-woman-youtube/story?id=11947003.

${ }^{260}$ THE WHITE HOUSE, supra note 109 , at 3; see Larson, supra note 109 , at 92. 
is appropriate to the sensitivity of the data and the risk of adverse consequences to consumers if the data is inaccurate."261

The House of Representatives is considering legislation that would provide for deletion of personal information from applications on mobile devices. ${ }^{262}$ California recently passed a new law that gives minors the right to erase posts they have made to online sites such as Facebook and Twitter. ${ }^{263}$ The Federal Trade Commission also has released recommendations for online consumer privacy ${ }^{264}$ and will have the ability to enforce compliance with a code of conduct that companies would adopt voluntarily. ${ }^{265}$ Companies like Google should want to comply with the FTC privacy program, according to its chairman, because "respecting consumer privacy and protecting data online encourages Internet commerce." $" 266$

Taking a lead on this issue is also in Google's corporate best interests as a company that touts transparency and doing no "evil."267 Right now, " $66 \%$ of search engine users say search

\footnotetext{
261 THE WHITE House, supra note 109, at 27; see Larson, supra note 109, at 92.

${ }^{262}$ Application Privacy, Protection, and Security Act, H.R. 1913, 113th Cong. (2013) ("The developer of a mobile application shall (1) provide a user of the application with a means of ... (B) requesting the developer .... (ii) at the option of the user, either (I) to the extent practicable, to delete any personal data collected by the application that is stored by the developer; or (II) to refrain from any further use or sharing of such data.").

${ }^{263}$ S.B. 568, 2013-2014 Leg., Reg. Sess. (Ca. 2013); INFOSECURITY, supra note 111 .

${ }^{264}$ F.T.C., F.T.C. RePort: Protecting CONSUMER PrivaCy IN AN ERA OF RAPID Change: ReCOMmENDATIONS FOR BUSINESSES AND POLICY MAKERS (Mar. 2012), available at http://www.ftc.gov/os/2012/03/120326privacyreport. pdf.

${ }^{265}$ Edward Wyatt, White House, Consumers in Mind, Offers Online Privacy Guidelines, N.Y. TIMES (Feb. 23, 2012), http://www.nytimes.com/2012/02/23/ business/white-house-outlines-online-privacy-guidelines.html?_r $=2 \&$ (reporting telephone call with Jon Leibowitz, chairman of the FTC).

${ }^{266} I d$.

${ }^{267}$ The Ten Things [Google] Know[s] to be True, GoOGLE, http://www. google.com/about/company/philosophy/ (last visited Feb. 5, 2014) (including "You Can Make Money Without Being Evil").
} 
engines are a fair and unbiased source of information." 268 Increasing transparency could increase that number.

Scholars have recommended technological, non-legal suggestions that are creative but not likely to be implemented any time soon: expiration dates on information; ${ }^{269}$ forgiveness by design or codebased solutions; ${ }^{270}$ or "reputation bankruptcy" where a person's online persona can be wiped clean. ${ }^{271}$ Ideas for non-legal solutions proliferate because legal solutions are not successful.

Other alternatives that would enforce a limited right to be forgotten online have problems of legal enforceability and harmful secondary effects. The notice-and-take-down regime of copyright law is a solution that has been suggested by scholars, ${ }^{272}$ but that system has been criticized for a tendency to chill speech. ${ }^{273}$ If Google were given the ultimate authority as to how to respond to take-down requests, it would not have the incentive to take down more rather than less speech. Others have suggested such a third party solution in the form of a court, ${ }^{274}$ an agency, ${ }^{275}$ or other

${ }^{268}$ PURCELL ET AL., supra note 14 , at 1.

269 VICTOR MAYER-SCHONBERGER, DELETE: THE VIRTUE OF FORGETTING IN ThE Digital AGE 171 (2009); see also Ambrose, You Are What Google Says You Are, supra note 64, at 23.

${ }^{270}$ ann Cavoukian \& JefF Jonas, Privacy by Design In the Age of Big DATA 7-9 (2012), available at http://privacybydesign.ca/content/uploads/2012/ 06/pbd-big_data.pdf.

${ }^{271}$ ZITTRAIN, supra note 36, at 228-29.

${ }^{272}$ See Ambrose, You Are What Google Says You Are, supra note 64, at 24; Ambrose, Seeking Digital Redemption, supra note 64; Abril, supra note 23, at 119-20.

${ }^{273}$ See Joshua Urist, Who's Feeling Lucky? Skewed Incentives, Lack of Transparency, and Manipulation of Google Search Results Under the DMCA, 1 BROOK. J. CORP. FIN. \& COM. L. 209, 211 (2006) (arguing that "the lack of transparency in the current notice and take down regime hobbles Internet speech, commerce, and technology by perpetuating a lopsided set of incentives for the removal of non-infringing material from the Internet.").

${ }^{274}$ See Moffat, supra note 42 , at 499 (recommending that the federal courts be given the task of regulating search engines, applying common law "in the interstices of the already-applicable federal statutes," including copyright and patent law, trademark law, the CDA, and antitrust law).

${ }^{275}$ See Oren Bracha \& Frank Pasquale, Federal Search Commission? Access, Fairness, and Accountability in the Law of Search, 93 CORNELL L. REV. 1149, 1202 (2008) (suggesting agency regulation). 
"trusted advisory committee."276 With either third party solution, though, the law would likely not allow mandating that Google act according to the third party's decision. Any requirement that Google take a specific action will likely violate First Amendment protection and/or the $\mathrm{CDA}^{277}$ Any requirement that Google "delete" certain search results would be, in addition, technically and logistically problematic. So Google should have the choice of remedy to effect suppression of the information so that it is no longer a top-ranked or first page search result. While there is already a mechanism for reporting images or other content on Google as inappropriate, it is not considered useful. ${ }^{278}$ The actual measures that Google uses could include adding ${ }^{279}$ or deleting tags from the problematic website so the information fails to appear or appears lower in response to search requests. ${ }^{280}$

${ }^{276}$ Pasquale, Restoring Transparency, supra note 37, at 247 (recommending a trusted third party advisory committed to the Federal Trade Commission overseeing search engines).

277 One proposal that might not run afoul of the law is Frank Pasquale's proposal that individuals be granted the right "not to suppress the results, but merely to add an asterisk to the hyperlink directing webusers to them, which would lead to the complainant's own comment on the objectionable result." Pasquale, Rankings, supra note 39, at 117.

${ }^{278}$ Nate Anderson describes the efforts of the Spanish park owner:

Years of trying to get [his concerns] addressed have had little effect. A regional IT consultant told him that the websites hosting the pictures had no interest in making any changes, so Mario decided to try Google. He began reporting the images as offensive, using Google's own tools, sometimes clicking on each five times a day; it had no result. He sent a certified letter to Google, begging them to associate the graphic images with searches for the accident and not with generic ones for his campground; they said there was nothing they could do. Anderson, supra note 15.

${ }^{279}$ See Ambrose, You Are What Google Says You Are, supra note 64, at 26 (discussing "Public Resource," a site that republishes court documents, which evaluates and grants requests from individuals identified in cases to remove the case from retrieval by Google). Public Resource will add a robots.txt file so that ethical crawlers will not index the page and it will not be presented in search results. The information is not deleted and is still accessible through the site, but not through a search. See id.

${ }^{280}$ In Spain, for example, Spanish citizens may file a complaint with the local data protection agency, and if the claim is found valid, the agency may order 
The benefits of a Google-driven approach include its pragmatism as well as its potential application in the EU as well as the United States. As noted in the recent report of the European Network and Information Security Agency, "[o]nce personal information is published, it is ultimately impossible to prevent, or even observe, by technical means, the creation of unauthorized copies of this information." ${ }^{281}$ Therefore, "[a] possible pragmatic approach to assist with the enforcement of the right to be forgotten is to require search engine operators and sharing services within the EU to filter references to forgotten information stored inside and outside the EU region." $" 282$ This approach is also consistent with the Charter signed recently in France endorsing a systematic online complaints procedure to deal with the diffusion of false or personal information. ${ }^{283}$

Finally, commentators advocate resorting to the free market approach. ${ }^{284}$ But a marketplace of ideas requires equal accesspeople need a way to seek removal of information that doesn't just increase the prominence of that information. ${ }^{285}$ Professor Grimmelmann notes the "enormous power" of linking a name with a piece of information, and how the truth cannot catch up with a falsehood. ${ }^{286}$ Here, unfortunately, the market is already not "free."

Google to remove the URL from its index. See Ambrose, Seeking Digital Redemption, supra note 64, at 158.

281 Peter Druschel, Michael Backes \& Rodica TiRTea, ENisa, The RIGHT TO BE FORGOTTEN - BETWEEN EXPECTATIONS AND PRACTICE 14 (2011).

${ }^{282} I d$. at 2.

${ }^{283}$ See Kate Brimsted, The right to be forgotten: can legislation put the data genie back in the bottle?, 11 PRIVACY \& DATA PROT. 4, 6 (Mar. 1, 2011) (noting that in October 2010, in France, "several internet businesses, including Microsoft, in collaboration with the French government signed a Charter on the right to 'cyber oblivion' within social networks and search engines. The voluntary Charter sets out six sets of obligations, including implementing a systematic online complaints procedure to deal with the diffusion of false or personal information." Google and Facebook were not signatories.).

${ }^{284}$ Eric Goldman, Search Engine Bias and the Demise of Search Engine Utopianism, 8 YALE J.L. \& TECH. 188, 200 (2006); see Moffat, supra note 42, at 490-91.

${ }^{285}$ See Chandler, supra note 72 , at 1108 (stating that "selection intermediaries" can themselves block speech from an audience).

${ }^{286}$ Grimmelmann, supra note 49 (manuscript at 17). 
People will try to take advantage of any proposed solution, and many requests will be meritless. But it is better to have a centralized, transparent process that does not require the money and time necessary to get a court order or to hire a reputation defender company.

\section{Conclusion}

Google is in a place of unprecedented power, given the shift in the way people get information. At the same time, it is in the daunting position of fostering free speech without promoting harmful speech. When Google's algorithm results in the prominent placement of defamatory comments, harassment, and cyberbullying in response to a search request, it is not remaining a neutral channel for open discussion, but is affirmatively assisting illegal activity. Google is immune from liability for the content it presents, but that should not mean it is blind to the effects. The right to be forgotten may be a legal non-starter in the United States. But the practical effects of harmful information could be greatly lessened by a recognition that false information is not as "relevant" as truthful information, no matter how popular it might be. 
